UNIVERSIDADE DE SÃO PAULO

ESCOLA DE ENFERMAGEM DE RIBEIRÃO PRETO

RICARDO JOSÉ FAGUNDES

\title{
AVALIAÇÃO DA DEGRADAÇÃO DE FORMOL DO EFLUENTE GERADO NO LABORATÓRIO DE ANATOMIA POR BIORREATORES ANAERÓBIOS E MAPEAMENTO DOS PONTOS CRÍTICOS DE CONTROLE
}

RIBEIRÃO PRETO 


\section{RICARDO JOSÉ FAGUNDES}

\section{AVALIAÇÃO DA DEGRADAÇÃO DE FORMOL DO EFLUENTE GERADO NO LABORATÓRIO DE ANATOMIA POR BIORREATORES ANAERÓBIOS E MAPEAMENTO DOS PONTOS CRÍTICOS DE CONTROLE}

Dissertação apresentada à Escola de Enfermagem de Ribeirão Preto da Universidade de São Paulo, para obtenção do título de Mestre em Ciências, Programa de Pós-Graduação em Enfermagem em Saúde Pública.

Linha de pesquisa: Saúde Ambiental

Orientador: Susana Inés Segura Muñoz

RIBEIRÃO PRETO 
Autorizo a reprodução e divulgação total ou parcial deste trabalho, por qualquer meio convencional ou eletrônico, para fins de estudo e pesquisa, desde que citada a fonte.

Fagundes, Ricardo José

AVALIAÇÃO DA DEGRADAÇÃO DE FORMOL DO EFLUENTE GERADO NO LABORATÓRIO DE ANATOMIA POR BIORREATORES ANAERÓBIOS E MAPEAMENTO DOS PONTOS CRÍTICOS DE CONTROLE. Ribeirão Preto, 2020. 60 p. : il. ; $30 \mathrm{~cm}$

Dissertação de Mestrado, apresentada à Escola de Enfermagem de Ribeirão Preto/USP. Área de concentração: Enfermagem em Saúde Pública.

Orientador: Susana Inés Segura Muñoz

1. Biodigestor. 2. Tratamento de Efluente. 3.Reator Anaeróbio Horizontal de Leito Fixo. 
FAGUNDES, Ricardo José

AVALIAÇÃO DA DEGRADAÇÃO DE FORMOL DO EFLUENTE GERADO NO LABORATÓRIO DE ANATOMIA POR BIORREATORES ANAERÓBIOS E MAPEAMENTO DOS PONTOS CRÍTICOS DE CONTROLE.

Dissertação apresentada à Escola de Enfermagem de Ribeirão Preto da Universidade de São Paulo, para obtenção do título de Mestre em Ciências, Programa de Pós-Graduação em Enfermagem em Saúde Pública.

Aprovado em / / /

Presidente

Prof. Dr.

Instituição:

Comissão Julgadora

Prof. Dr.

Instituição:

Prof. Dr.

Instituição:

Prof. Dr.

Instituição: 


\section{AGRADECIMENTOS}

Primeiramente, agradeço a Deus, pela oportunidade proporcionada no caminho por ele traçado. Por ser sempre aquele que me guia, me protege e me ilumina.

A você leitor, pelo interesse em buscar esse trabalho e pela atenção dedicada à leitura.

A minha orientadora Profa. Dra ${ }^{a}$. Susana Inés Segura-Muñoz, pela paciência e sabedoria transmitida. Agradeço o apoio e a experiência. Obrigado por tudo!

À minha família. À minha esposa, Nadiele, pelo amor, companheirismo e carinho. Agradeço também por toda apoio, força e incentivo. Aos meus filhos, João Miguel e Júlia Valentina, pelo afeto e pelas alegrias. A todos os meus familiares, pelo apoio e alegrias.

Aos meus colegas André, Flávio, Jaqueline, Marco, Maria Verônica e a Vânia, que sempre me incentivaram na realização e conclusão deste trabalho. Obrigado pelo companheirismo, pelos auxílios e por fazer o ambiente de trabalho mais agradável!

Agradeço especialmente à Dra . Vânia Brazão Muniz, pela disponibilidade, ajuda e pelas valiosas considerações. A você, o meu muito obrigado!

Aos colegas Dr. Adriano César Pimenta e Dr. Danilo Vitorino dos Santos pela disponibilidade, ajuda, considerações, treinamento e paciência. Muito obrigado!

O presente trabalho foi realizado com apoio da Coordenação de Aperfeiçoamento de Pessoal de Nível Superior - Brasil (CAPES) - Código de Financiamento 001

À Escola de Enfermagem de Ribeirão Preto - Universidade de São Paulo, pela oportunidade!

A todos que contribuíram direta ou indiretamente para concretização deste trabalho, muito obrigado! 


\section{RESUMO}

FAGUNDES, R. J. Avaliação da degradação de formol do efluente gerado no laboratório de anatomia por biorreatores anaeróbios e mapeamento dos pontos críticos de controle. 2021. 57 f. Dissertação (Mestrado em Ciências) - Escola de Enfermagem de Ribeirão Preto, Universidade de São Paulo, Ribeirão Preto.

Diante das estratégias de ensino e aprendizagem adotadas na disciplina de Anatomia da Escola de Enfermagem de Ribeirão Preto da Universidade de São Paulo (EERP/USP), que requer a conservação de peças cadavéricas em solução de formol, no Laboratório Multidisciplinar são gerados significantes volumes de efluentes contendo este composto. Considerando as características tóxicas dessa substância, tanto aos seres vivos quanto ao meio ambiente, torna-se imprescindível o gerenciamento e tratamento deste resíduo gerado antes do descarte na rede coletora de esgotos. Embora diferentes métodos, sejam eles químicos ou biológicos, possam ser utilizados para promover o tratamento prévio ao descarte de soluções contendo formol, o uso de tratamentos biológicos, como o reator anaeróbio, possibilita o tratamento de grandes volumes de resíduos, gera menor exposição ocupacional e possui reduzido custo do processo. No ano de 2017 a EERP/USP implementou o Reator Anaeróbio Horizontal de Leito Fixo (RAHLF), dimensionado para atender grandes volumes de efluentes com solução de formol gerados na unidade. Neste contexto, este estudo inédito em escala industrial, além de monitorar a eficiência da remoção da solução de formol dos efluentes gerados do sistema de biorreatores também caracterizamos os pontos críticos de controle do processo de tratamento do RAHLF, durante o período de fevereiro a junho e de setembro a novembro do ano de 2020. Os resultados na entrada do RAHLF apresentaram uma média de

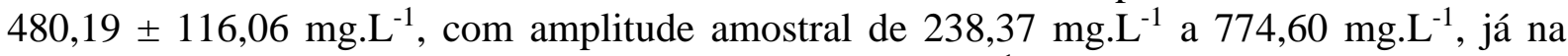
saída do RAHLF demonstraram média de 1,39 $\pm 0,56 \mathrm{mg} . \mathrm{L}^{-1}$, com amplitude amostral de 0,04 mg. $\mathrm{L}^{-1}$ a 2,32 mg. $\mathrm{L}^{-1}$, evidenciando assim a eficiência na degradação do formol pelos biorreatores em média de 99,70\%. A partir dos dados foi evidenciado que além do desempenho satisfatório do RAHLF para o pré-tratamento de água residuária contendo formol, o reator também apresentou estabilidade de operação durante o desenvolvimento do estudo. Com o conhecimento de todas as etapas e dos pontos críticos do processo foi possível a organização do fluxograma do processo, desde o local gerador até a disposição do efluente para a rede coletora de esgoto municipal. A partir do fluxograma, foi possível desenvolver protocolo de operação, visando minimizar ao máximo potenciais ocorrências de falhas durante o processo. Este estudo gerou conhecimento que contribui para melhor compreensão da biotecnologia anaeróbia implantada para alcançar a degradação da solução de formol no efluente do Laboratório Multidisciplinar da EERP/USP. A implantação e funcionamento adequado do biodigestor refletem o compromisso socioambiental da universidade com a sociedade e com o meio ambiente, na busca de ações que promovam tanto a saúde pública quanto a sustentabilidade ambiental. Os resultados constituirão também uma base de dados para outros gestores de biodigestores implantados na universidade, sendo de grande importância para a continuidade de investigações relacionadas com o tratamento dos efluentes em laboratórios de ensino.

Palavras-Chave: Biodigestor. Tratamento de Efluente. Reator Anaeróbio Horizontal de Leito Fixo. 


\begin{abstract}
FAGUNDES, R. J. Evaluation of formalin degradation of effluent generated in the anatomy laboratory by anaerobic bioreactors and mapping of critical control points. 2021. 60 f. Dissertation (Master's thesis) - College of Nursing in Ribeirão Preto, University of São Paulo, Ribeirão Preto.
\end{abstract}

For the development of teaching and learning strategies adopted in the discipline of Anatomy at the University of São Paulo at College of Nursing in Ribeirão Preto (CNRP/USP), which requires the preservation of cadaveric parts in a formaldehyde solution, the Multidisciplinary Laboratory generates significant volumes of effluents containing this compound. Considering the toxic characteristics of this substance, both to living beings and to the environment, it is essential to manage and treat this wastewater before its disposal in the sewage collection system. Although different methods, whether chemical or biological, can be used to promote treatment prior to disposal of solutions containing formaldehyde, the use of biological treatments, such as the anaerobic reactor, allows the treatment of large volumes of waste, generates less occupational exposure and has reduced process cost. In 2017, EERP/USP implemented the Anaerobic Horizontal Fixed Bed Reactor (AHFBR), dimensioned to supply large volumes of wastewater with a formaldehyde solution generated at the unit. In this context, this unprecedented study on an industrial scale, in addition to monitoring the efficiency of the removal of the formaldehyde solution from the effluents generated from the bioreactor system, we also characterized the critical control points of the AHFBR treatment process, during the period from February to June and from September to November of 2020. The results of the affluent of the AHFBR presented an average of $480.19 \pm 116.06 \mathrm{mg} . \mathrm{L}^{-1}$, with a sample range of $238.37 \mathrm{mg} . \mathrm{L}^{-1}$ to $774.60 \mathrm{mg}$. $\mathrm{L}^{-1}$, already in the effluent of the AHFBR obtained average of $1.39 \pm 0.56 \mathrm{mg} . \mathrm{L}^{-1}$, with a sample range of $0.04 \mathrm{mg} . \mathrm{L}^{-1}$ to $2.32 \mathrm{mg} . \mathrm{L}^{-1}$, thus evidencing the efficiency in formaldehyde degradation by bioreactors on average of $99.70 \%$. From the data, it evidenced that in addition to the satisfactory performance of the AHFBR for the pre-treatment of wastewater containing formaldehyde, the reactor also showed operating stability during the development of the study. With the knowledge of all the steps and critical points of the process, it was possible to organize the process flowchart, from the generating site to the disposal of the effluent to the municipal sewage collection network. From the flowchart, it was possible to develop an operation protocol, aiming to minimize as many potential occurrences of failures during the process as possible. This study generated knowledge that contributes to a better understanding of the anaerobic biotechnology implemented to achieve the degradation of the formaldehyde solution in the effluent of the Multidisciplinary Laboratory at CNRP/USP. The implantation and proper functioning of the biodigester reflect the university's socio-environmental commitment to society and the environment, in the search for actions that promote both public health and environmental sustainability. The results will also constitute a database for other managers of biodigesters implemented at the university, being of great importance for the continuity of investigations related to the treatment of effluents in teaching laboratories

Keywords: Biodigester. Effluent Treatment. Anaerobic Horizontal Fixed Bed Reactor. 


\section{RESUMEN}

FAGUNDES, R. J. Evaluación de la degradación de formalina del efluente generado en el laboratorio de anatomía por biorreactores anaeróbicos y mapeo de puntos críticos de control. 2021. 60 f. Disertación (Maestría) - Escuela de Enfermería de Ribeirão Preto, Universidad de São Paulo, Ribeirão Preto.

Para las estrategias de enseñanza y aprendizaje adoptadas en la disciplina de Anatomía en la Escuela de Enfermería de Ribeirão Preto de la Universidad de São Paulo (EERP / USP), que requiere la preservación de partes cadavéricas en una solución de formaldehído, el Laboratorio Multidisciplinario genera importantes volúmenes de efluentes. que contiene este compuesto. Dadas las características tóxicas de esta sustancia, tanto para los seres vivos como para el medio ambiente, es fundamental gestionar y tratar estos residuos generados antes de su disposición en el sistema de alcantarillado. Si bien se pueden utilizar diferentes métodos, ya sean químicos o biológicos, para promover el tratamiento previo a la eliminación de soluciones que contienen formaldehído, el uso de tratamientos biológicos, como el reactor anaeróbico, permite el tratamiento de grandes volúmenes de residuos, genera menos exposición ocupacional y ha costo de proceso reducido. En 2017, EERP/USP implementó el Reactor Anaeróbico Horizontal de Lecho Fijo (RAHLF), dimensionado para suministrar grandes volúmenes de efluentes con una solución de formaldehído generada en la unidad. En este contexto, en este inédito estudio a escala industrial, además de monitorear la eficiencia de la remoción de la solución de formaldehído de los efluentes generados por el sistema biorreactor, también caracterizamos los puntos críticos de control del proceso de tratamiento de RAHLF, durante el período de febrero a junio y de septiembre a noviembre de 2020. Los resultados de lo afluente de la RAHLF presentaron un promedio de $480.19 \pm 116.06 \mathrm{mg} . \mathrm{L}^{-1}$, con un rango de muestra de $238.37 \mathrm{mg} . \mathrm{L}^{-1}$ a $774.60 \mathrm{mg}^{-\mathrm{L}^{-1}}$, ya el efluente del RAHLF mostró una media de $1.39 \pm 0.56 \mathrm{mg} . \mathrm{L}^{-1}$, con un rango de muestra de $0.04 \mathrm{mg} . \mathrm{L}^{-1}$ a $2.32 \mathrm{mg} . \mathrm{L}^{-1}$, evidenciando así la eficiencia en la degradación del formaldehído por biorreactores en promedio $99,70 \%$. A partir de los datos se evidenció que además del desempeño satisfactorio del RAHLF para el pretratamiento de aguas residuales que contienen formaldehído, el reactor también mostró estabilidad operativa durante el desarrollo del estudio. Con el conocimiento de todos los pasos y puntos críticos del proceso, fue posible organizar el diagrama de flujo del proceso, desde el sitio de generación hasta la disposición del efluente a la red de alcantarillado municipal. A partir del diagrama de flujo, fue posible desarrollar un protocolo de operación, con el objetivo de minimizar la mayor cantidad posible de ocurrencias de fallas durante el proceso. Este estudio generó conocimiento que contribuye a una mejor comprensión de la biotecnología anaeróbica implementada para lograr la degradación de la solución de formaldehído en el efluente del Laboratorio Multidisciplinario de la EERP/USP. La implantación y buen funcionamiento del biodigestor reflejan el compromiso socioambiental de la universidad con la sociedad y el medio ambiente, en la búsqueda de acciones que promuevan tanto la salud pública como la sostenibilidad ambiental. Los resultados también constituirán una base de datos para otros gestores de biodigestores implementados en la universidad, siendo de gran importancia para la continuidad de las investigaciones relacionadas con el tratamiento de efluentes en los laboratorios docentes.

Palabras claves: Biodigestor. Tratamiento de efluentes. Reactor Anaeróbico Horizontal de Lecho Fijo. 


\section{LISTA DE FIGURAS}

Figura 1 Esquema da Sala para Conservação das Peças Cadavéricas do Laboratório Multidisciplinar da EERP/USP.

Figura 2 Esquema da Interligação do Local de Geração ao Biodigestor na EERP/USP......27

Figura 3 Esquema da vista superior do RAHLF para o tratamento do efluente contendo formol gerado na EERP/USP.

Figura 4 Esquema da vista lateral do RAHLF para o tratamento do efluente contendo formol gerado na EERP/USP.

Figura 5 Esquema da vista lateral do RAHLF para o tratamento do efluente contendo formol gerado na EERP/USP.

Figura 6 Esquema do RAHLF para o tratamento do efluente contendo formol gerado na EERP/USP com os pontos de coleta de amostra. 30

Figura 7 Curva de Calibração para determinação da concentração do formol pelo método de Bailey \& Rankin, 1971.

Figura 8 Concentrações médias de formol (mg.L $\left.\mathrm{L}^{-1}\right)$ no afluente e efluente do RAHLF da EERP/USP, obtidas através de método colorimétrico, durante o período de análise.

Figura 9 Distribuição dos dados de $\mathrm{pH}$ das amostras do afluente e efluente do RAHLF da EERP/USP, no período de fevereiro a junho e setembro a novembro de 2020

Figura 10 Sala para Conservação das Peças Cadavéricas (Local Gerador). .42

Figura 11 Caixa de Registros.

Figura 12 Caixa Intermediária......

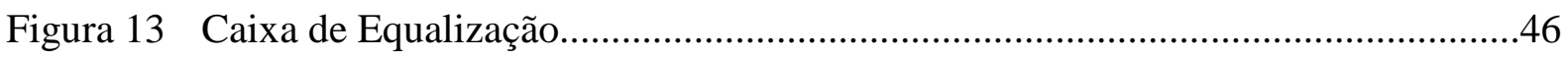

Figura 14 Bomba dosadora da marca FCE modelo FCE 0505 ...........................................47

Figura 15 Bomba dosadora de modelo JBB25/1.0...........................................................

Figura 16 Biorreatores.

Figura 17 Fluxograma do mapeamento do processo do sistema de tratamento implantado na EERP/USP

Figura 18 Fluxograma do mapeamento do processo do envio do efluente do local gerador até a rede coletora de esgoto descrito com os pontos críticos 


\section{LISTAS DE TABELAS}

Tabela 1 Critérios utilizados da FMEA para identificação dos índices de ocorrência, severidade e detecção de falhas no processo de tratamento de efluentes contendo formol do Laboratório Multidisciplinar da EERP/USP.......................................35

Tabela 2 Distribuição das concentrações médias de formol (mg.L $\mathrm{L}^{-1}$ ) das amostras coletadas do afluente e efluente do sistema de tratamento (RAHLF) da EERP/USP, no período de fevereiro a junho e setembro a novembro de 2020 . .39

Tabela 3 Distribuição das concentrações da solução enviada para o RAHLF da EERP/USP e a sua eficiência ocorrida nos dias 09 e 16 de dezembro 2019.......43 


\section{SUMÁRIO}

1. INTRODUÇÃ

2. OBJETIVOS ................................................................................................ 16

2.1. Objetivo Geral ......................................................................................... 16

2.2. Objetivos Específicos ……………………….......................................................... 16

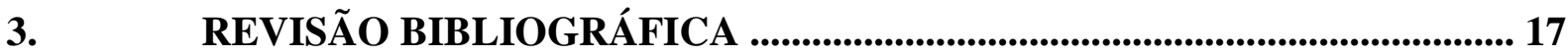

3.1. Ensino de Anatomia em cursos superiores da área da saúde ........................... 17

3.2. Preservação e manipulação de peças anatômicas ............................................... 18

3.3. Fixadores e conservantes de peças anatômicas ................................................... 19

3.4. Toxicidade do formaldeído para a saúde humana ............................................ 21

3.5. Mapeamento de processo e identificação de potenciais de falhas ................... 22

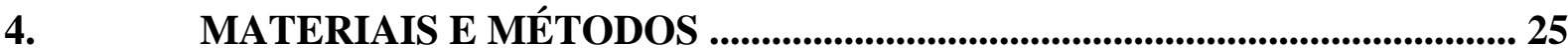

4.1. Local de Estudo ......................................................................................................... 25

4.1.1. Sala para Conservação de Peças Cadavéricas ....................................................... 25

4.1.2. Interligação dos Tanques da Sala para Conservação de Peças Cadavéricas ao

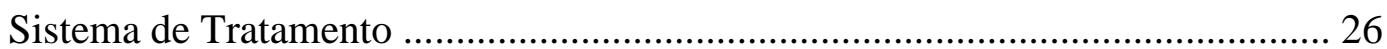

4.1.3. Reator Anaeróbio Horizontal de Leito Fixo (RAHLF) ……………………….... 27

4.2. Amostragem ..................................................................................................... 30

4.3. Suprimentos nutricionais para os biorreatores .................................................. 31

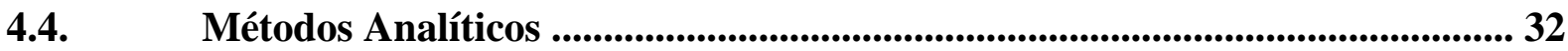

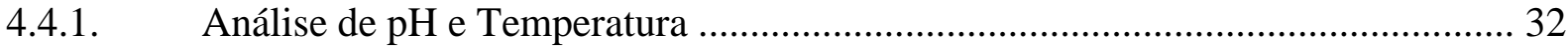

4.4.2. Análise de quantificação do formol presente nas amostras ................................. 32

4.4.2.1. Preparação da solução tampão de fosfato dissódico-ácido cítrico de pH 5,6 .... 32

4.4.2.2. Reagente $1 \%$ de dicloreto de p-fenilenodiamina $\left(\mathrm{C}_{6} \mathrm{H}_{8} \mathrm{~N}_{2} .2 \mathrm{HCl}\right)$....................... 32

4.4.2.3. Curva de Calibração ....................................................................................... 33

4.4.2.4. Método colorimétrico de Bailey e Rankin (1971) ............................................... 34

4.5. Mapeamento dos pontos críticos do processo de tratamento do efluente contendo formol ................................................................................................................ 34

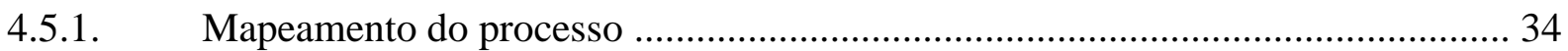

4.5.2. Identificação dos pontos críticos do processo ................................................... 35

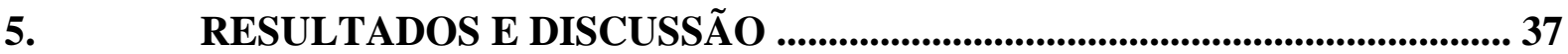

5.1. Avaliação do desempenho do RAHLF, com determinação das concentrações da solução de formol no afluente e efluente do sistema ...................................... 37 
5.2. Mapeamento e identificação dos pontos críticos do processo de tratamento de efluentes contendo formol ............................................................................................... 42

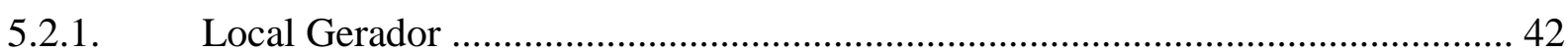

5.2.2. Interligação dos Tanques da Sala para Conservação de Peças Cadavéricas até o

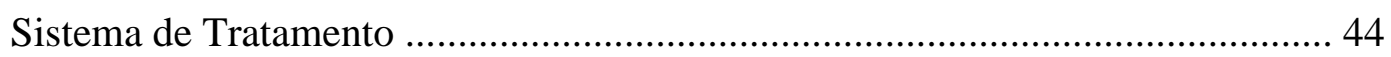

5.2.3. Reator Anaeróbio Horizontal de Leito Fixo (RAHLF) ...................................... 45

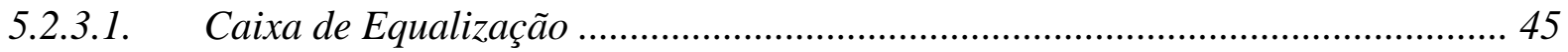

5.2.3.2. Bomba dosadora do Suprimento Nutricional ..................................................... 46

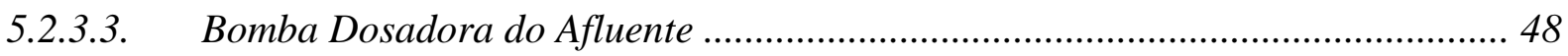

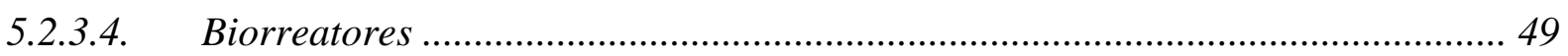

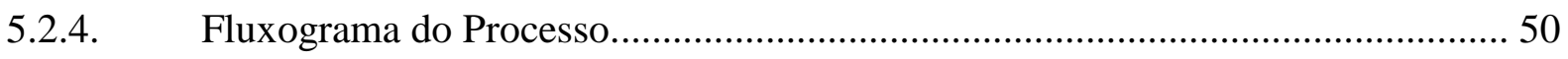

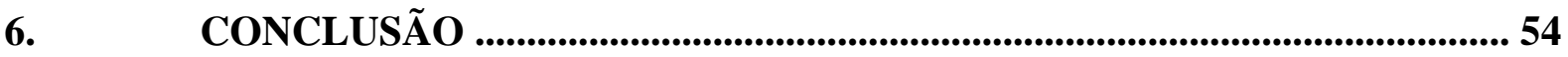

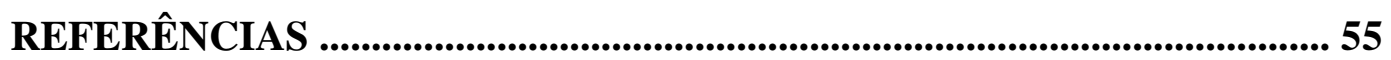




\section{INTRODUÇÃO}

A Anatomia Humana é uma das ciências médicas mais antigas, que estuda as estruturas macroscópicas e microscópicas do corpo humano, sendo considerada uma disciplina fundamental para a formação dos profissionais da área saúde, uma vez que seu entendimento é necessário para a excelência do exercício profissional (MOMPEO; PEREZ, 2003; TAVANO; OLIVEIRA, 2008).

A maioria das instituições que conduzem cursos da área da saúde têm como principal recurso de ensino a utilização de peças cadavéricas, assim, todos os estudantes aprendem as estruturas do corpo humano que foram sistematicamente dissecadas e dessa forma, adquirem o conhecimento das terminologias anatômicas (VAN DE GRAAF, 2003). Este processo de ensino-aprendizagem em anatomia humana é muito utilizado no Brasil (SILVA et al, 2016). A dissecação ou anatomização cadavérica possui grande importância para a compreensão estrutural e funcional do corpo humano, formando a base das disciplinas de histologia, anatomia e fisiologia humana.

Essa estratégia de ensino é de grande importância tanto no aprendizado das estruturas anatômicas do corpo humano, quanto no aprendizado de questões éticas. Esta última, trabalha o envolvimento do discente em relação ao outro ser humano, afim de que os aspectos técnicos sejam diretamente interligados aos preceitos ético-humanísticos, com respeito ao próximo mesmo após o falecimento (COSTA, 2012).

Para o desenvolvimento das estratégias de ensino e aprendizagem em anatomia, é necessário que seja feita a devida fixação, conservação e dissecação do cadáver, tendo como procedimento primário a fixação deste em solução de formol, que é o produto químico mais utilizado para este processo (RODRIGUES, 2005).

A fixação do cadáver é realizada através da injeção de um volume de 10 litros da solução de formol a 3,7\% pela artéria femoral. Após a infusão, o cadáver é submerso em um tanque contendo a mesma solução, permanecendo por um período mínimo de seis meses para a completa fixação e início da dissecação. As dissecações são executadas por profissionais envolvidos diretamente nas disciplinas de Anatomia. Realizado este procedimento, o cadáver está preparado para aula prática. Entretanto, após a dissecação é necessária a manutenção das peças cadavéricas submersas na solução de formol, devido a ação antimicrobiana deste composto que evita a decomposição (JUNQUEIRA; CARNEIRO, 2005).

A volatilidade, odor penetrante e toxicidade da solução de formol são considerados pontos negativos na utilização de peças cadavéricas em aula práticas de anatomia (SILVA et 
al, 2016). Pela experiência dos profissionais de instituições de ensino superior, adota-se como procedimento a diluição da concentração do formol presente nas peças cadavéricas com a submersão em água em período anterior a serem utilizadas. Dessa forma são diminuídos os efeitos adversos pelo potencial de aspiração de vapores emanados pelas peças (SILVA et al, 2016). Porém, a água residual resultante desse processo de submersão das peças anatomopatológicas apresenta concentração de formol em média de $600 \mathrm{mg} . \mathrm{L}^{-1}$, sendo portanto, considerada tóxica, e tal solução deve ser submetida a um tratamento prévio, antes do descarte na rede coletora de esgotos (OLIVEIRA, 2001).

O lançamento do efluente que contém solução de formol do laboratório de anatomia na rede coletora municipal de esgoto é proibido devido ao impacto ambiental que pode ocasionar, prejudicando o desempenho das Estações de Tratamento de Esgoto (ETEs) que utilizam sistemas biológicos de degradação de matéria orgânica (QU; BHATTACHARYA, 1997). De acordo com a legislação estadual de São Paulo, por meio do decreto ${ }^{\circ} 8.468$ de 8 de setembro de 1976 (São Paulo, 1976) foi aprovado o regulamento da Lei no 997 de 31 de maio de 1976 que define poluente como:

\footnotetext{
Art. $3^{\circ}$ - Considera-se poluente toda e qualquer forma de matéria ou energia lançada ou liberada nas águas, no ar ou no solo:

I - com intensidade, em quantidade e de concentração, em desacordo com os padrões de emissão estabelecidos neste Regulamento e normas dele decorrentes;

II - com características e condições de lançamentos ou liberação, em desacordo com os padrões de condicionamento e projeto estabelecidos nas mesmas prescrições;

III - por fontes de poluição com características de localização e utilização em desacordo com os referidos padrões de condicionamento e projeto;

IV - com intensidade, em quantidade e de concentração ou com características que, direta ou indiretamente, tornem, ou possam tornar ultrapassáveis os padrões de qualidade do meio-ambiente, estabelecidos neste Regulamento e normas dele decorrentes;

$\mathrm{V}$ - que, independentemente, de estarem enquadrados nos incisos anteriores, tornem ou possam tornar as águas, o ar ou o solo impróprios, nocivos ou ofensivos à saúde; inconvenientes ao bem estar público; danosos aos materiais, à fauna e à flora prejudiciais à segurança, ao uso e gozo da propriedade, bem como às atividades normais da comunidade.
}

O descarte inapropriado da solução de formol representa um risco significativo à saúde pública e ao meio ambiente, havendo a necessidade de um tratamento preliminar (PHILIPPI Jr., 2005). A Lei 12.305 de 02 de agosto de 2010 aponta os geradores como responsáveis pelos resíduos produzidos. Esta lei institui a Política Nacional de Resíduos Sólidos e dispõe as diretrizes relativas à gestão integrada e ao gerenciamento de resíduos sólidos, semissólidos e líquidos, incluídos os perigosos, fornecendo responsabilidade para os geradores e ao poder público. 
Considerando a legislação estadual apresentada, as instituições de ensino e pesquisa devem assegurar/garantir o gerenciamento dos resíduos gerados, a fim de evitar danos à saúde pública e ao meio ambiente.

Até no ano de 2005 a disciplina de Anatomia Humana era oferecida para os alunos da EERP/USP utilizando a infraestrutura e docência da Faculdade de Medicina de Ribeirão Preto (FMRP/USP). No ano de 2009, a EERP/USP inaugurou o Laboratório Multidisciplinar, localizado no Conjunto de Laboratórios Didáticos e de Pesquisa "Profa. Dra. Neide Fávero, e que faz parte do Centro de Simulação de Práticas de Enfermagem. Ainda no ano de 2009, esta escola recebeu a doação de um cadáver para fins de ensino, razão pela qual houve a necessidade de uma reestruturação, com a implantação da Sala para Conservação de Peças Cadavéricas, que ocorreu em 2011, com a instalação de cubas de inox, guincho e sistemas de exaustão. Até então, em razão do pequeno volume de formol gerado, a EERP/USP armazenava o produto a ser descartado em recipientes fechados para posterior encaminhamento ao Laboratório de Resíduos Químicos (LRQ) da Prefeitura do campus USP Ribeirão, setor responsável pelo processamento e descarte dessas substâncias tóxicas.

Diante da legislação vigente, o campus universitário da Universidade de São Paulo (USP) em Ribeirão Preto, através do Plano Diretor Ambiental e dos Grupos de Trabalho (GTs), coordenados pela Comissão Técnica de Gestão Ambiental (CTGA-RP) do Campus, visando a garantia da sustentabilidade ambiental do Campus e o atendimento à legislação, optou pela construção de três sistemas de tratamento de água residual com capacidade de degradar a solução de formol de unidades da área da saúde. Os biodigestores foram construídos a partir do projeto do RAHLF desenhado, desenvolvido e validado por Oliveira (2001). Dessa forma a EERP/USP implementou o RAHLF no ano de 2017, em consonância com modelo publicado por Oliveira (2001), dimensionado para atender o volume de efluentes com solução de formol da unidade.

Neste contexto, tornou-se necessário o contínuo monitoramento da eficiência da remoção de formol dos efluentes gerados no sistema de tratamento instalado. Também, ficou evidenciada a necessidade de realizar o mapeamento das etapas de tratamento para monitoramento do processo e identificação dos pontos críticos de controle do processo, motivos que justificaram o desenvolvimento do presente estudo. 


\section{OBJETIVOS}

\subsection{Objetivo Geral}

Avaliar o sistema de tratamento de efluentes contendo solução de formol do Laboratório Multidisciplinar da EERP/USP.

\subsection{Objetivos Específicos}

a)Determinar a concentração da solução de formol no afluente e efluente do biodigestor;

b)Mapear e caracterizar o processo de tratamento do biodigestor anaeróbio de resíduo de formol e identificar os pontos críticos de controle do processo. 


\section{REVISÃO BIBLIOGRÁFICA}

\subsection{Ensino de anatomia em cursos superiores da área da saúde}

A Anatomia Humana é uma das ciências médicas mais antigas, sendo que os primeiros relatos de seu estudo e ensino foram descritos há milênios em civilizações antigas. O aprimoramento de técnicas para caçar animais bem como a seleção de suas partes destinadas ao consumo e descarte, eram processos que exigiam determinado conhecimento anatômico, são os primeiros indícios da origem da Anatomia (PIAZZA; CHASSOT, 2011). O período histórico de grande importância para a Anatomia ocorreu no ano 384 a.c., quando Aristóteles nomeia a aorta, a principal artéria do corpo humano (MOSLEY; LYNCH, 2011). Registros de Galeno destacam as primeiras dissecações públicas de animais e corpos humanos (SINGER, 1996).

Porém, diante dos grandes questionamentos sobre a temática das dissecações para fins de estudo, foi apenas na Europa, a partir do século XIV, na Universidade de Bolonha, e com orientação de Mondino de Luzzi (1270-1326), que o ensino de anatomia começou a fazer parte do ensino médico. Neste período, os estudos anatômicos baseavam-se principalmente na tradução de obras e tratados de anatomia, com a dissecação sendo um método de averiguação de dados preexistentes.

Durante o período do Renascimento, a ilustração criada por Leonardo da Vinci (1452-1519) denominada "O Homem Vitruviano", é considerada o símbolo da Anatomia. Em 1543, Andreas Vesalius publica o primeiro Tratado de Anatomia De humani corporis fabrica (A estrutura do corpo humano, 1543), com a inclusão dos principais órgãos, nervos e músculos do corpo humano (MOSLEY; LYNCH, 2011). Dante Bertelli, em 1932, descreve a Anatomia, tornando-a eixo fundamental de todas as outras ciências médicas, sem a qual as demais não poderiam subsistir (DI DIO, 1998).

A Anatomia é uma ciência indispensável para o conhecimento e compreensão da constituição e o desenvolvimento dos seres vivos. A palavra Anatomia tem origem grega anatome, sendo que "ana" significa "através de" e "tome" refere-se a "corte", sendo o termo incialmente usado por Aristóteles. Na atualidade, a Anatomia é reconhecida como uma disciplina básica nos dois primeiros anos dos cursos na área da saúde (NEVES, 2010), permitindo assim a interligação com diversas disciplinas subsequentes.

Mompeo e Perez (2003) destacam que o conhecimento de Anatomia é essencial para as ciências que formam profissionais da área da saúde e afins, uma vez que seu entendimento 
é necessário para a formação de profissionais qualificados. O ensino da Anatomia humana, nas últimas décadas, tem vivenciado muitas mudanças estruturais, em decorrência das reformas curriculares dos cursos da área da saúde. Tais modificações são consideradas primordiais para o enquadramento nas novas diretrizes curriculares dos cursos de graduação (FORNAZIERO et al., 2010).

Diversas estratégias de ensino-aprendizagem são utilizadas no processo de construção do conhecimento da anatomia humana, tais como uso de modelos sintéticos de resina e recursos tecnológicos. O uso de modelos anatômicos é uma ferramenta importante no ensino, que possibilita ao aluno estabelecer analogias, compreender as conexões existentes entre os diferentes órgãos, interligando os conhecimentos adquiridos com conteúdo de outras áreas do conhecimento, explorando dessa forma, habilidades e competências imprescindíveis.

Porém, diversos pesquisadores destacam a importância do uso de cadáveres como método de aprendizagem mais adequado para o ensino de Anatomia humana (DA NOVA; BEZERRA FILHO; BASTOS, 2000; BABINSKI et al., 2003; RIZZOLO; STEWART, 2006; ANYANWU; UDEMEZUE; OBIKILI, 2011; COLLIPAL; SILVA, 2011; FAZAN, 2011; KERBY; SHUKUR; SHALOUB, 2011). Da Nova, Bezerra Filho e Bastos (2000) ainda ressaltaram que o impacto promovido pelo contato do estudante com o cadáver traz importantes reflexões sobre temas tais como: a dignidade humana, a sexualidade, a mortalidade e o luto.

\subsection{Preservação e manipulação de peças anatômicas}

No Brasil, as instituições de ensino de anatomia que utilizam a metodologia pedagógica de uso de peças cadavéricas humanas têm como fonte cadáveres não reclamados provenientes do Instituto Médico Legal conforme permitido pelo Código Civil Brasileiro, na Lei $n^{\circ}$ 8.501/1992 (Brasil, 1992). Para esse fim, deve ser respeitado o período de trinta dias, além de ser realizada a publicação do óbito nos principais jornais pelo período mínimo de dez dias. O artigo 14 da Lei n ${ }^{\circ} 10.406$ de 2002 afirma que pode tornar válida a doação voluntária em vida para fins científicos ou objetivos altruístas após a sua morte (BRASIL, 2002). Entretanto, é importante destacar que os processos de doação são dependentes do consentimento dos familiares, seja de primeiro ou segundo grau, regerão que é assegurado pelo artigo 4 da Lei $n^{\circ}$ 9.434/1997 (BRASIL, 1997). É primordial que o laboratório de anatomia da instituição que receberá a doação, arquive a documentação gerada e todo o processo de doação, contendo dados relativos às características gerais, identificação, fotos do 
corpo, ficha datiloscópica, resultado da necropsia (se efetuada) e quaisquer outros dados e documentos pertinentes (BRASIL, 1992).Para o estudo morfológico dos tecidos humanos na disciplina de Anatomia Humana é necessária a prévia fixação e preservação do corpo humano, afim de interromper a ação dos agentes microbiológicos e enzimáticos envolvidos com os processos de putrefação (GONZÁLEZ; CASTRO, 1989; FERREIRA et al., 2017).

Inicialmente o álcool etílico foi amplamente utilizado entre os séculos XVIII e XIX. Em 1867, durante o seminário internacional no Museu de Anatomia de Viena, um outro conservante foi apresentado, sendo uma combinação de glicerina, álcool etílico e ácido carbólico (GONZÁLEZ; CASTRO, 1989; FERREIRA et al., 2017), com uma importante ação devido a capacidade de fixar um grande volume de tecido. No entanto, a partir de 1886 a glicerina veio como um novo fixador de peças cadavéricas.

No final do século XIX e início do século XX, a utilização da solução de formol se popularizou devido ao seu baixo custo e alto poder de penetração nos tecidos. Entretanto, existem alguns fatores negativos associados ao uso desta solução como a necessidade de manter constantemente as peças submersas em solução de formol à $3,7 \%$, aliado ao fato de que este produto químico volátil ocasiona grande irritabilidade no trato respiratório e nos olhos dos usuários durante a manipulação das peças cadavéricas (OLIVEIRA et al, 2013), o que requer procedimentos de segurança e utilização de equipamentos de proteção individual (SANTOS et al, 2017).

Um dos procedimentos adotados pelas instituições de ensino para diminuir a irritabilidade ocasionada pela presença de formol é a imersão das peças cadavéricas em um tanque de diluição preenchido totalmente com água. Dessa forma, é diminuída a concentração deste composto químico nas peças cadavéricas e consequentemente são reduzidos os efeitos da irritabilidade ocasionados por ele.

\subsection{Fixadores e conservantes de peças anatômicas}

$\mathrm{Na}$ anatomia, além de preservar, as técnicas de conservação de peças anatômicas objetivam manter as características morfológicas dos componentes anatômicos quanto à coloração, consistência e flexibilidade de tecidos. Diversas substâncias estabilizadoras podem ser utilizadas neste processo, tais como: formaldeído, glicerina, álcool etílico e o fenol.

A solução de formol é uma solução líquida, incolor e de odor picante, sendo comercializada na concentração de $37 \%$ e estabilizada com $10 \%$ de metanol. Apresenta outras propriedades físico-químicas como: $\mathrm{pH}$ de 2,8 a 4,0, ponto de fusão de $-15^{\circ} \mathrm{C}$, ponto de 
ebulição de $93-96^{\circ} \mathrm{C}$, ponto de fulgor $62^{\circ} \mathrm{C}$, densidade de $1,09 \mathrm{~g} / \mathrm{cm}^{3}$ em $20^{\circ} \mathrm{C}$, solúvel em água (FISPQ, 2017). O formol é um composto que apresenta grande volatilidade, de odor forte, tóxico, irritante para as mucosas (RODRIGUES, 2005; TAVANO e OLIVEIRA, 2008), causando desconfortos, tais como, irritação nos olhos, vias aéreas e garganta, dores de cabeça e náuseas. $\mathrm{O}$ emprego incorreto do formol pode trazer prejuízos para o meio ambiente, sendo também considerado carcinogênico pelo Instituto Nacional do Câncer (INCA).

A glicerina, substância com ação fungicida e bactericida, utilizada na preservação de peças anatômicas, é um composto menos agressivo e que reduz a liberação de vapores no ambiente (ALVARENGA, 1992; SILVA et al., 2008). A glicerina foi descrita em 1762 por Karl Wilhelm Sheele (SILVA et al, 2008), sendo inicialmente utilizada na preservação de corpos pelo anatomista Carlo Giacomini (GIGEK et al, 2009).

O uso de glicerina refinada é considerado um método eficiente de conservação de peças anatômicas, além de ser menos tóxico para os manipuladores, mantêm a integridade dos tecidos, sem o odor desagradável como visto nas peças preservadas com a solução de formol. Porém, o elevado custo desta substância, com preço quase dez vezes maior quando comparado à solução de formol (KRUG et al, 2011), e a necessidade de um tempo de impregnação da substância de aproximadamente quinze dias, inviabilizam o seu uso em muitos laboratórios de anatomia no país.

Outro composto que tem sido utilizado de forma isolada na fixação e preservação de animais de pequeno porte e pequenas peças anatômicas é o álcool etílico ( $96^{\circ} \mathrm{GL}$ ). Além de possuir baixo custo e facilidade de aquisição, esta substância conta com grande afinidade e alto poder de penetração nos tecidos (RODRIGUES, 2005). A técnica de Laskowski, por exemplo, consiste na perfusão de álcool etílico $96^{\circ} \mathrm{GL}$ associado a ácido fênico e bórico nas cavidades e vasos dos cadáveres. Porém, estudos destacam o risco genotóxico dos compostos fenólicos para os manipuladores (RODRIGUES, 2005).

A Plastinação, procedimento criado na Alemanha pelo médico, anatomista, artista e cientista Gunther Von Hagens em 1977, é uma técnica moderna que permite a preservação de matéria biológica, sendo inodora, atóxica e mantém a coloração, bem como as relações entre os órgãos e sistemas, nervos, vasos, procedimentos cirúrgicos e processos patológicos. Tal técnica, simplificadamente, consiste na extração dos líquidos corporais (água e soluções fixadoras) e dos lipídios presentes nas peças cadavéricas, com o emprego de agentes químicos, e na substituição destes por resinas plásticas como por exemplo silicone, poliéster e epóxi. 
Dentre os diversos benefícios que a plastinação traz, pode-se citar: melhor conservação e durabilidade dos corpos e tecidos, diminuição da manutenção, possibilita uma morfologia semelhante à natural das estruturas, não possui odores, diminuindo assim a insalubridade durante a manipulação das peças cadavéricas. Adicionalmente, o uso de silicone durante a plastinação garante melhores resultados, quanto à flexibilidade das peças, nível de retração tecidual e coloração. A grande desvantagem deste procedimento é o alto custo operacional, visto que requer maior investimento em infraestrutura, incluindo aquisição de equipamentos tais como freezers adaptados e estritas normas de segurança.

\subsection{Toxicidade do formaldeído para a saúde humana e meio ambiente}

$\mathrm{O}$ formaldeído (fórmula molecular $\mathrm{H}_{2}-\mathrm{C}=\mathrm{O}$; CAS 50-00-0) foi descoberto em 1867 pelo químico alemão A. W. Von Hofmann. É um gás incolor, inflamável e altamente reativo à temperatura ambiente (CARMO; PRADO, 1999), que pode ser obtido comercialmente como solução aquosa a 30-50\% (m/m), conhecida por formalina. O formaldeído se caracteriza por apresentar as seguintes propriedades: massa molar 30,03 g.mol ${ }^{-1}$, densidade 1,03-1,07, ponto de fusão $-92^{\circ} \mathrm{C}$, ponto de ebulição $-19,1^{\circ} \mathrm{C}$ e solúvel em água, etanol e clorofórmio (KADEN et al. 2010).

O aldeído é absorvido pelo organismo principalmente por via respiratória. A penetração por via dérmica é usualmente baixa, enquanto a via digestiva representa uma situação esporádica, ocorrendo apenas em situações acidentais ou por contaminação alimentar. A exposição ao formaldeído pode causar irritação nos olhos, nariz e no trato respiratório, tendo sido frequentemente associada à exacerbação da asma, especialmente em crianças mais sensíveis (MCGWIN et al., 2010).

A inalação de formaldeído também pode provocar inflamação das mucosas das vias respiratórias, sendo produzidos mediadores inflamatórios, desencadeadoras de crises asmáticas (ELIAS, et al. 2003). Recentemente foi demonstrado que o formaldeído pode alterar os mecanismos bioquímicos das substâncias com grupos tiol (SH), conduzindo a uma acelerada redução do broncodilatador endógeno S-nitrosoglutationa, constituindo outra via de desencadeamento de doenças respiratórias (THOMPSON et al., 2008).

A penetração por inalação é ocasionada devido a solubilidade do formaldeído em água, que é altamente absorvido no sistema respiratório, sendo este fortemente metabolizado a ácido fórmico. Tanto formaldeído quanto o ácido fórmico, não são acumulativos de forma 
significativa por qualquer tecido humano, sendo estes pertencentes ao metabolismo intermediário (ALVES; ACIOLE, 2012).

O formaldeído absorvido pode sofrer conversão à formiato (formato ou metanoato), que é o sal ou éster do ácido fórmico, o qual apresenta três importantes vias. O composto pode ser inicialmente excretado na urina, ser incorporado a outras moléculas celulares ou ainda pode ser oxidado a dióxido de carbono e exalado do organismo. Além destas possibilidades, o formaldeído pode apresentar outras vias, como a reação instantânea com aminas primárias e secundárias, tióis, hidroxilas e amidas, com a formação de derivados de metilol $\left(-\mathrm{CH}_{2} \mathrm{OH}\right)$. Também pode ligar-se de forma reversível à cisteína para formar tiazolidina-4-carboxilato. Adicionalmente, pode reagir com a ureia originando adutos hidroximetila ou, ainda, ligar-se à macromoléculas como o ácido desoxirribonucleico (DNA), ácido ribonucleico (RNA) e proteínas, desencadeando a formação de adutos tanto reversíveis quanto irreversíveis (ALVES; ACIOLE, 2012 e IARC, 2006).

Estudos experimentais evidenciam que os efeitos tóxicos e carcinogênicos decorrentes da exposição ao formaldeído são ocasionados em virtude da saturação da Desidrogenase do Formaldeído (ADH3) ou da depleção da Glutationa (GSH). Embora em humanos, além da ADH3, sejam descritas várias outras enzimas, deve-se destacar que as duas enzimas principais responsáveis pela metabolização do formaldeído livre são a Desidrogenase de Aldeído Citosólica de Classe 1 (ALDH1) e a Desidrogenase de Aldeído Mitocondrial de Classe 2 (ALDH2). Adicionalmente, tais estudos relataram polimorfismos genéticos como responsáveis pela elevada redução da capacidade de oxidação do formaldeído (ALVES; ACIOLE, 2012).

Além da ação tóxica aos seres vivos, o formol em virtude da baixa biodegradabilidade pode ocasionar imensos prejuízos ao meio ambiente. Este composto pode causar danos aos sistemas de tratamento biológicos, e quando depositado inadequadamente no solo, o formol pode ser lixiviado em direção às águas subterrâneas, provocando contaminações nos lençóis freáticos e comprometendo a vida aquática.

\subsection{Mapeamento de processo e identificação de potenciais falhas}

O mapeamento de processos é definido como uma técnica em que os processos de determinado setor, departamento ou organização são colocados em um diagrama, a fim de se obter orientações para as fases de avaliação, projeto e desenvolvimento (CHEUNG; BAL, 1998), ou seja, uma ferramenta utilizada para a identificação da sequência lógica das 
atividades que compõem o mesmo. O uso deste instrumento permite aquisição de conhecimento, documentação, padronização, melhoria e transformação dos processos. Desta forma, são possíveis as identificações de obstáculos, delimitações das funções, recursos, custos e desempenho. O mapeamento pode ser gerado através de uma representação gráfica contendo informações a respeito da entrada, processamento e saída do produto gerado. Com o resultado, é imprescindível a validação do processo por terceiros. Após a conclusão, é possível o apontamento das possíveis melhorias e otimizações. Com as remodelações refeitas e validadas, passa-se para a etapa de treinamento da equipe envolvida e possíveis automatizações que poderão ocorrer no processo.

O mapeamento deverá apresentar um acompanhamento periódico dos resultados, comprovando a eficiência e a produtividade da organização. Assim demonstrando a eficiência do processo com os indicadores de performances e o envolvimento de toda a equipe.

Falhas são eventos ou ocorrências que ocasionam a inadequação do recurso para o uso (BLACHE; SHRIVASTAVA, 1994). A falha na execução de uma determinada função exigida (RAUSAND; OIEN, 1996), ou um evento indesejado também podem ser responsáveis por erros e mau funcionamento do processo (ALMEIDA et al, 2006). Entretanto, não há operação que seja isenta de falhas, mesmo que alguns serviços sejam cruciais, estes podem ocasionar prejuízos de grandes proporções (SLACK et al, 2002).

Visando a minimização ou eliminação da ocorrência de falhas e, consequentemente, a otimização da confiabilidade do processo, diversas técnicas e métodos podem ser aplicados (FAGUNDES; ALMEIDA, 2004). Como exemplo, a técnica de Análise dos Modos e Efeitos de Falhas (FMEA sigla em inglês: Failure Mode and Effects Analysis) que é amplamente utilizada em vários setores, devido a sua indicação em normas como ISO 9004, QS 9000 e entre outras (ARAÚJO et al, 2001). Esta metodologia analítica sistemática e padronizada, consiste na identificação de todas as possíveis potenciais falhas e determinar o efeito de cada uma sobre o desempenho do sistema, produto ou processo, mediante um raciocínio basicamente dedutivo (HELMAN; ANDERY, 1995).

Consiste, portanto, na identificação de todos os possíveis modos potenciais de falha e determina o efeito de cada uma sobre o desempenho de um sistema, seja este um produto ou um processo. É um método de estudo das causas fundamentais dos problemas de produtos e/ou processos, e tem como principal objetivo identificar e hierarquizar as falhas críticas, apontando o potencial de risco de cada uma e auxiliando a elaboração de um plano de ação para o bloqueio das falhas detectadas (MATOS; MILAN, 2009). 
Araújo et al (2001) classifica em dois tipos a FMEA. Primeiro a FMEA de produto que identifica cada componente do sistema e os possíveis modos de falha associados, bem como seus efeitos no sistema em questão e no produto como um todo. E o segundo tipo é FMEA de processo, que é realizada através da análise detalhada do sistema, identificando os seus potenciais de falhas e seus efeitos (PALADY, 1997). Dessa forma, é possível identificar variáveis de processo que devem ser monitorizadas, assim priorizando as tomadas de ações preventivas ou corretivas. Para isto, primeiramente é necessário a elaboração de um fluxograma indicando detalhes para cada etapa (BASTOS, 2006). Estas informações devem ser apresentadas por um formulário (PALADY, 1997) e procedimento construtivo (SHARMA et al, 2005).

Adicionalmente, Mello e Salgado (2005) destacam que para o adequado gerenciamento de um processo faz-se necessário a visualização deste. E para tal, podem ser empregadas diferentes técnicas de mapeamento, como por exemplo o fluxograma de processo. Barnes (2004) define que o fluxograma consiste no registro de forma compacta de um processo, no qual são utilizados símbolos padronizados (BARNES, 2004).

Dentre outras técnicas disponíveis, o fluxograma é um método que além das informações necessárias proporciona a ordenação de atividades e direciona para as possíveis interrupções para decisão e implementação de estratégias. 


\section{MATERIAIS E MÉTODOS}

\subsection{Local de Estudo}

O estudo foi conduzido no município de Ribeirão Preto, que está localizado a Noroeste da Capital do Estado de São Paulo, apresenta uma área de $650.916 \mathrm{~km}^{2}$, uma população estimada de 711.825 habitantes, índice de escolarização de 96,9\%, índice de desenvolvimento humano municipal de 0,800, mortalidade infantil 10,67 óbitos por mil nascidos vivos e uma renda per capita de $\mathrm{R} \$ 49.425,29$ (IBGE, 2021). Além da importância econômica a cidade é destaque nas áreas de saúde abrigando importantes centros de referências, biotecnologia, bioenergia, tecnologia de informação, educação, pesquisas, turismos de negócios e cultura do Brasil.

A EERP/USP foi criada no dia 26 de dezembro de 1951 pela lei estadual 1467 sendo anexada à FMRP/USP. Em 1975 a escola foi transferida para o prédio próprio dentro do Campus Universitário de Ribeirão Preto (EERP, 2020).

O Centro de Simulação de Práticas de Enfermagem possui o Laboratório Multidisciplinar localizado no Conjunto de Laboratórios Didáticos e de Pesquisa "Profa. Dra. Neide Fávero" da EERP/USP. Este laboratório foi inaugurado em junho de 2009, é composto por três salas, a primeira utilizada para atividades práticas com os alunos, a segunda para atividades administrativas e a terceira para armazenamento de materiais de consumo e insumos. Após 2011, esta última sala foi reestruturada para Sala para Conservação de Peças Cadavéricas, a qual conta com bancada, cubas de inox e cubas de vidro, guincho e sistemas de exaustão. Em 2017, com o objetivo de oferecer o tratamento adequado ao efluentes contendo formol, antes do envio destes para a rede de esgoto, houve a implantação do RAHLF (OLIVEIRA, 2001; OLIVEIRA et al., 2004), para a degradação do grande volume de efluente gerado.

\subsubsection{Sala para Conservação de Peças Cadavéricas}

Esta sala é composta por três tanques. O tanque interno 1 com dimensões de 192 x 78 x $69 \mathrm{~cm}(\mathrm{C}$ x L x P), o tanque interno 2 com dimensões de 120 x 80 x $70 \mathrm{~cm}$ (C x L x P) e o tanque interno 3 com dimensões de 192 x 78 x $69 \mathrm{~cm}$ (C x L x P). Todos estes apresentam um registro independente dentro da canaleta de piso para o controle de escoamento e armazenamento da solução dentro dos mesmos (Figura 1). 
Os dois primeiros tanques têm a função de armazenamento das peças cadavéricas existentes no Laboratório Multidisciplinar, ou seja, apresentam a solução de formol a 3,7\% para a conservação por submersão das mesmas. O terceiro tanque, tem a função de diluição, pois como descrito previamente, para a utilização das peças cadavéricas em aulas práticas da disciplina de Anatomia é necessário um período de submersão em água para diminuir a concentração de formol e consequentemente o nível de exposição aos usuários.

A canaleta de piso para coleta, além de conter os registros dos tanques, também possui a função de coletar a solução caso ocorra um possível transbordamento de conteúdo destes tanques.

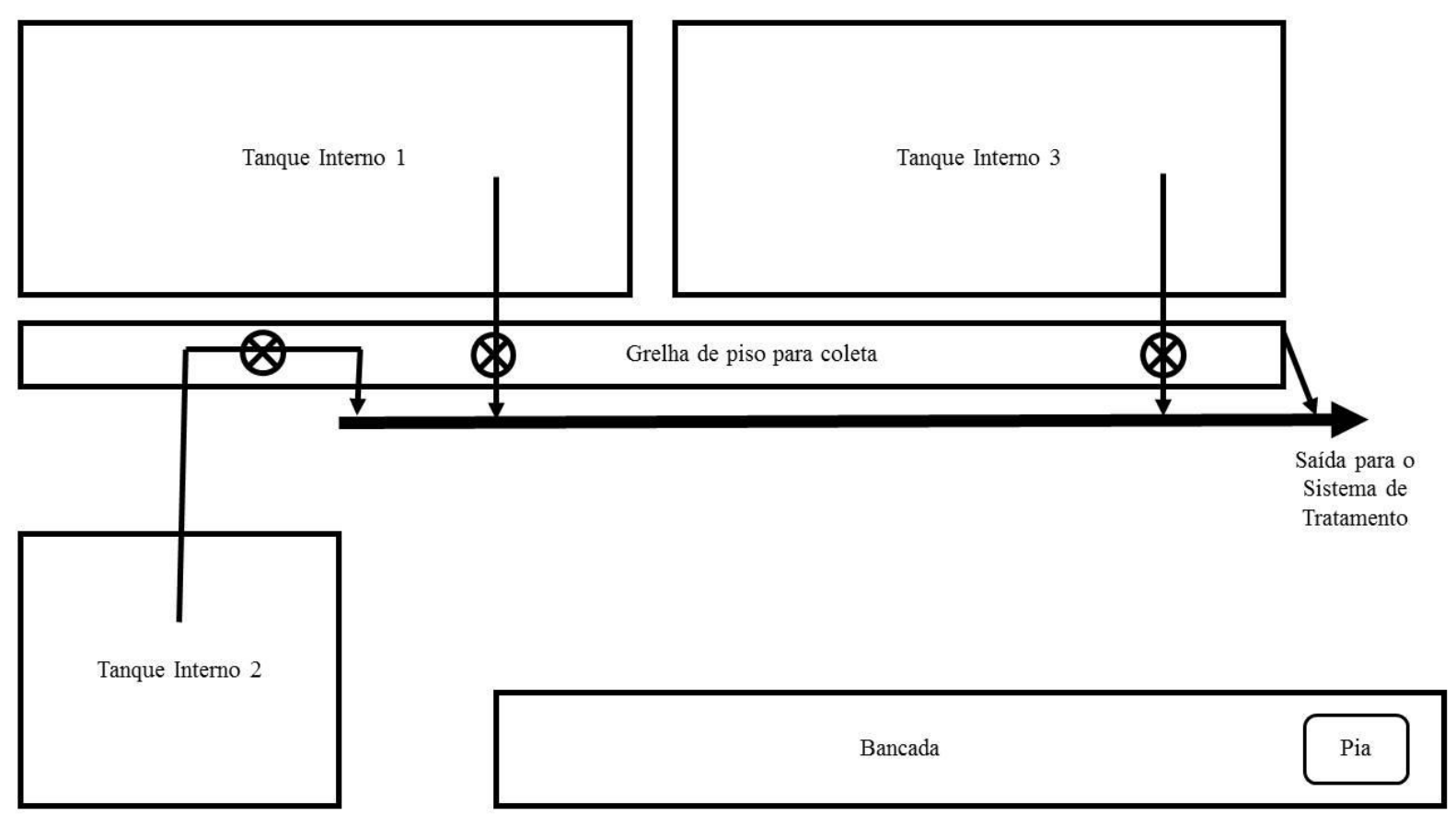

Figura 1- Esquema da Sala para Conservação das Peças Cadavéricas do Laboratório Multidisciplinar da EERP/USP.

4.1.2. Interligação dos Tanques da Sala para Conservação de Peças Cadavéricas ao Sistema de Tratamento.

Com a implantação do RAHLF para a degradação dos efluentes gerados pelo Laboratório Multidisciplinar, foi necessária a construção de uma estrutura intermediária interligando o local de geração de resíduo contendo formol ao biodigestor, resultando em duas estruturas principais e uma secundária.

A primeira estrutura principal é a Caixa dos Registros, responsável por direcionar o efluente para dois possíveis destinos: Rede de Esgotos ou Caixa Intermediária (Figura 2). 
A segunda estrutura principal é a Caixa Intermediária, que é uma caixa d'água de 1000L. Tal caixa foi instalada na primeira reestruturação do Laboratório Multidisciplinar em 2011, para que ocorresse uma diluição do efluente contendo formol como uma forma de minimização dos danos ambientais associados a este resíduo químico. Posteriormente, para o tratamento adequado do efluente gerado na Sala para Conservação de Peças Cadavéricas foi conduzida a implantação do RAHLF e a reestruturação das instalações existentes.

A terceira estrutura secundária é uma caixa de inspeção de cimento, como uma forma de manutenção e prevenção nas tubulações destas interligações.

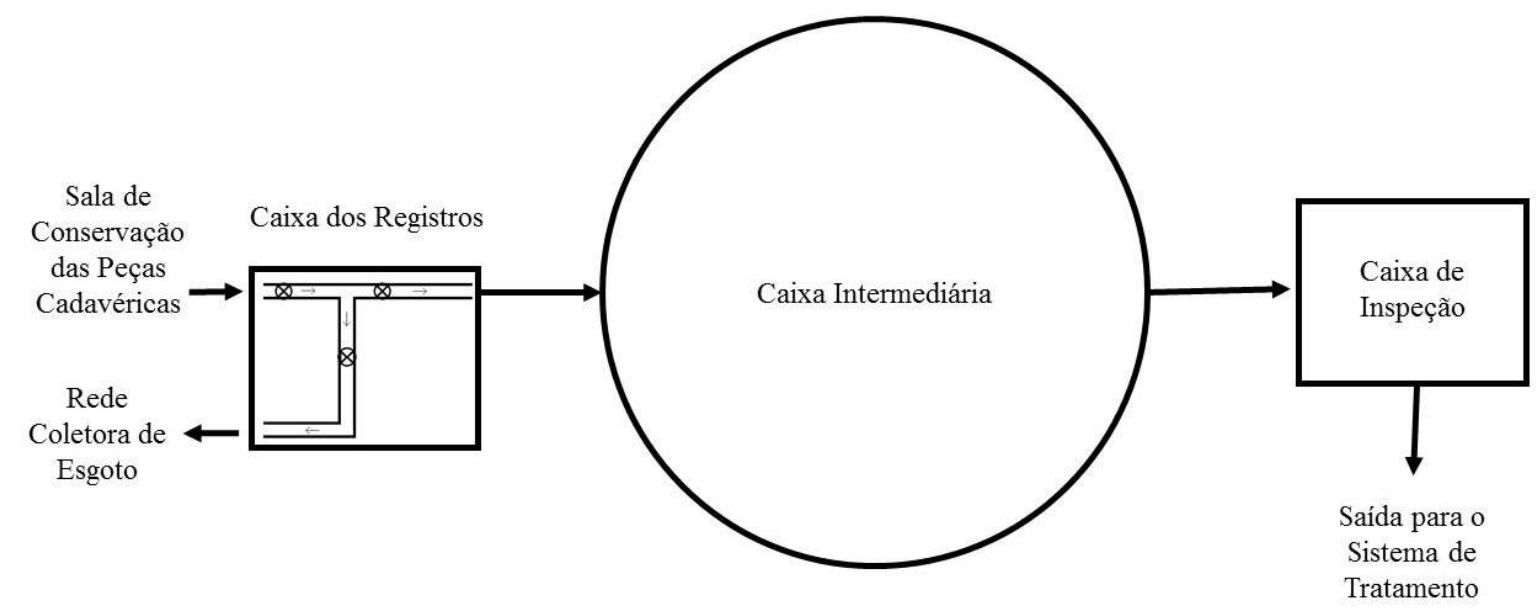

Figura 2- Esquema da Interligação do Local de Geração ao Biodigestor na EERP/USP.

\subsubsection{Reator Anaeróbio Horizontal de Leito Fixo (RAHLF)}

O biodigestor está localizado no subsolo ao lado do Bloco Maria Cecília Puntel, cuja inauguração ocorreu em 2017. É composto por uma Caixa de Equalização de 1.000 L, dez tubos de policloreto de vinila (PVC), com dimensões de $3 \mathrm{~m}$ de comprimento e $150 \mathrm{~mm}$ de diâmetro cada, além de duas Bombas Dosadoras.

A estrutura do sistema é dividida em duas áreas distintas, sendo que na primeira área estão instaladas as bombas dosadoras, as quais direcionam o efluente da Caixa de Equalização para os biorreatores, e a infraestrutura elétrica, para o funcionamento das bombas e da iluminação. Na segunda área estão a Caixa de Equalização, que recebe o efluente gerado do laboratório de anatomia, e os biorreatores que fazem o tratamento deste resíduo produzido (Figura 3).

Visando a coleta de amostras, foram instalados registros, denominados de amostradores, que podem ser encontrados em diferentes locais como na entrada do sistema, 
entre os tubos e na saída para a rede de esgoto. Para a saída do biogás (metano e gás carbônico) produzido pelos reatores, foram instalados adaptadores para a sua liberação para o meio externo.

Os tubos foram preenchidos com espuma de poliuretano (em formato de cubo com dimensões de $1,5 \mathrm{~cm}$ e densidade de $23 \mathrm{~kg} / \mathrm{m}^{3}$ ) e misturados com lodo de esgoto, proveniente de uma Estação de Tratamento de Esgotos de Indústria Avícola. O efluente enviado pela bomba dosadora modelo JBB25/1.0 passa por estes tubos, onde é realizada a degradação do formol.

Conforme a norma da Companhia Ambiental do Estado de São Paulo (CETESB), mesmo com a realização do tratamento prévio, é necessária o envio do efluente para Estação de Tratamento de Esgoto Municipal através da rede coletora de esgotos.

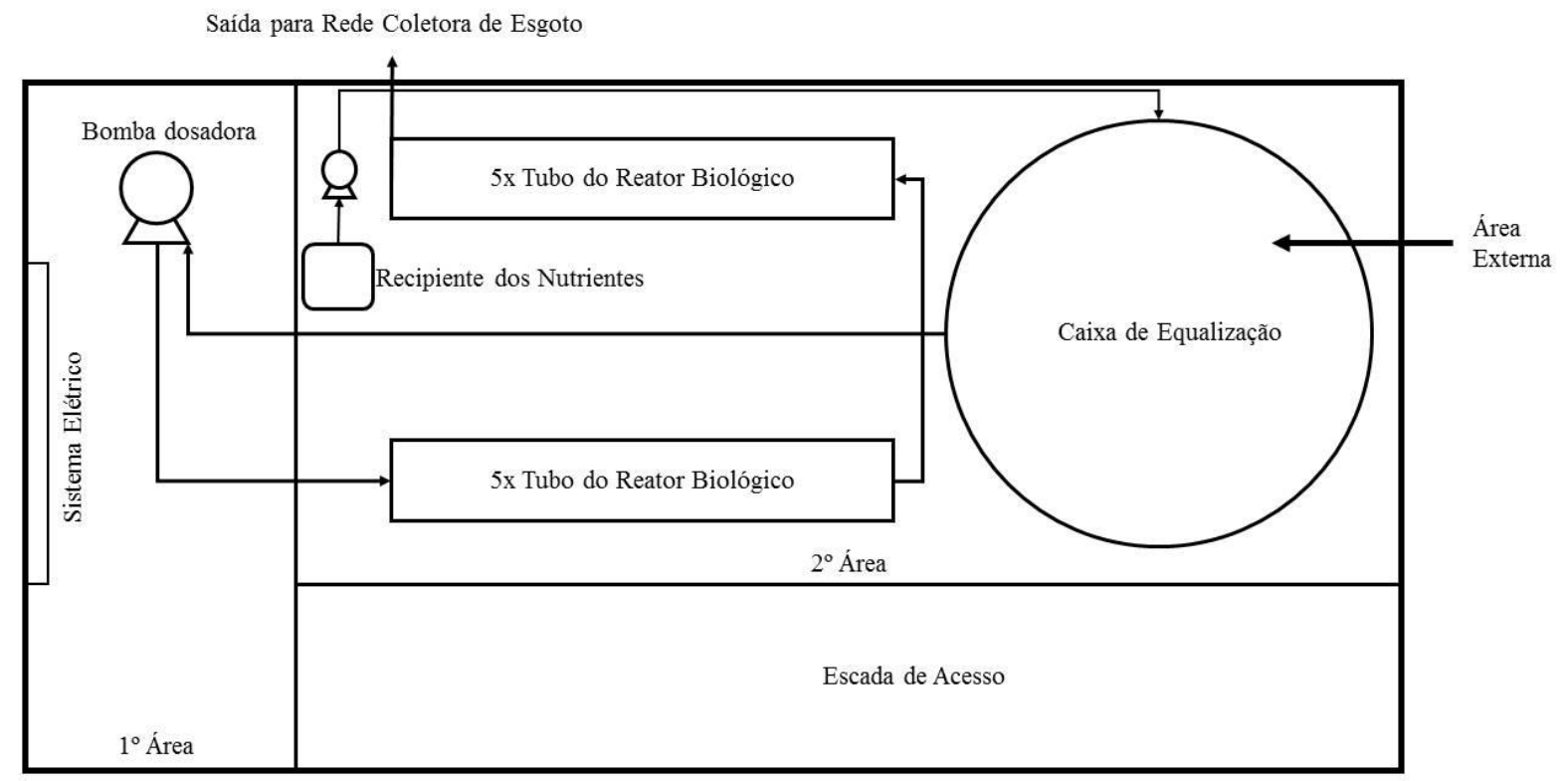

Figura 3- Esquema da vista superior do RAHLF para o tratamento do efluente contendo formol gerado na EERP/USP. 


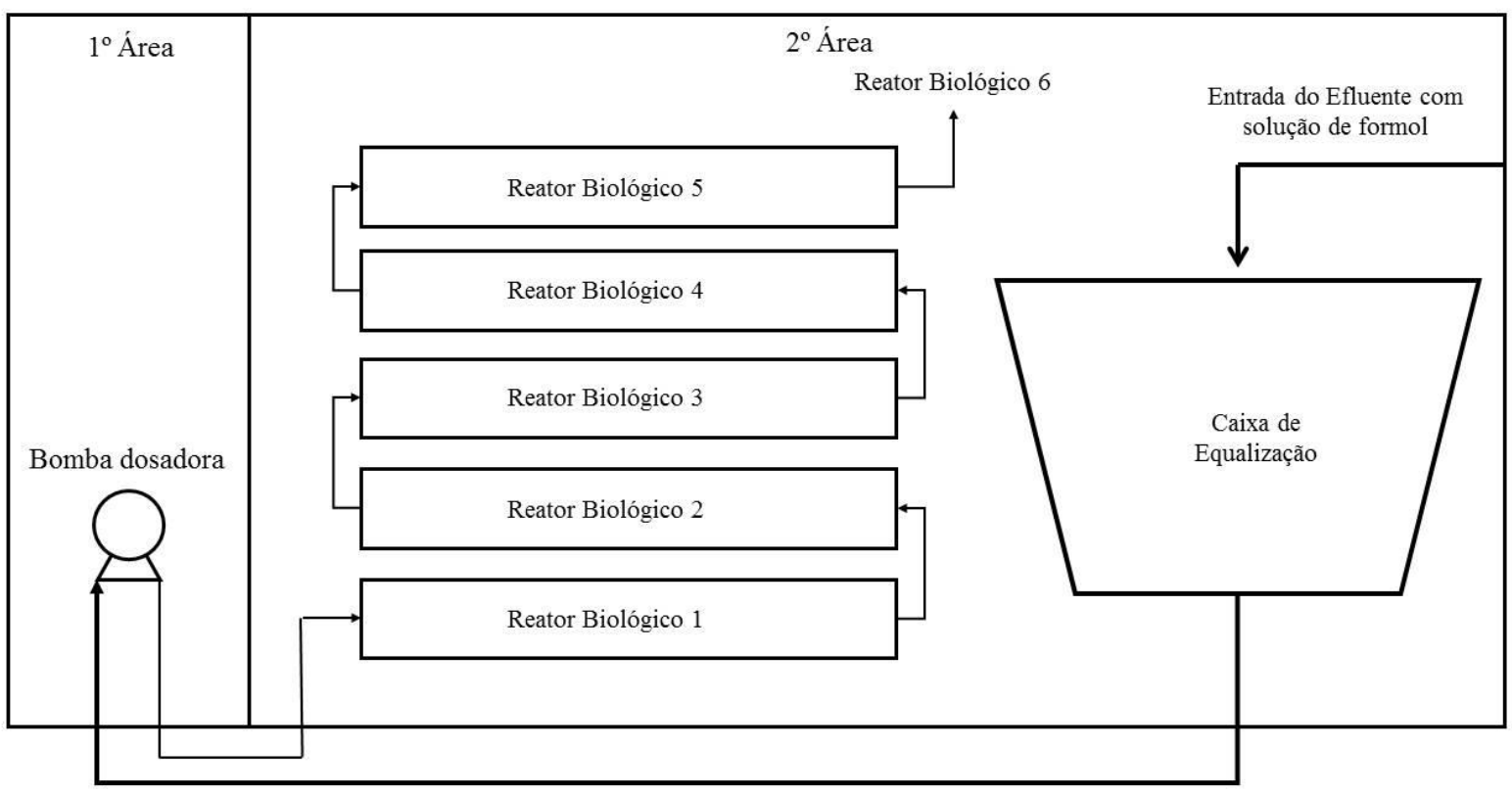

Figura 4- Esquema da vista lateral do RAHLF para o tratamento do efluente contendo formol gerado na EERP/USP.

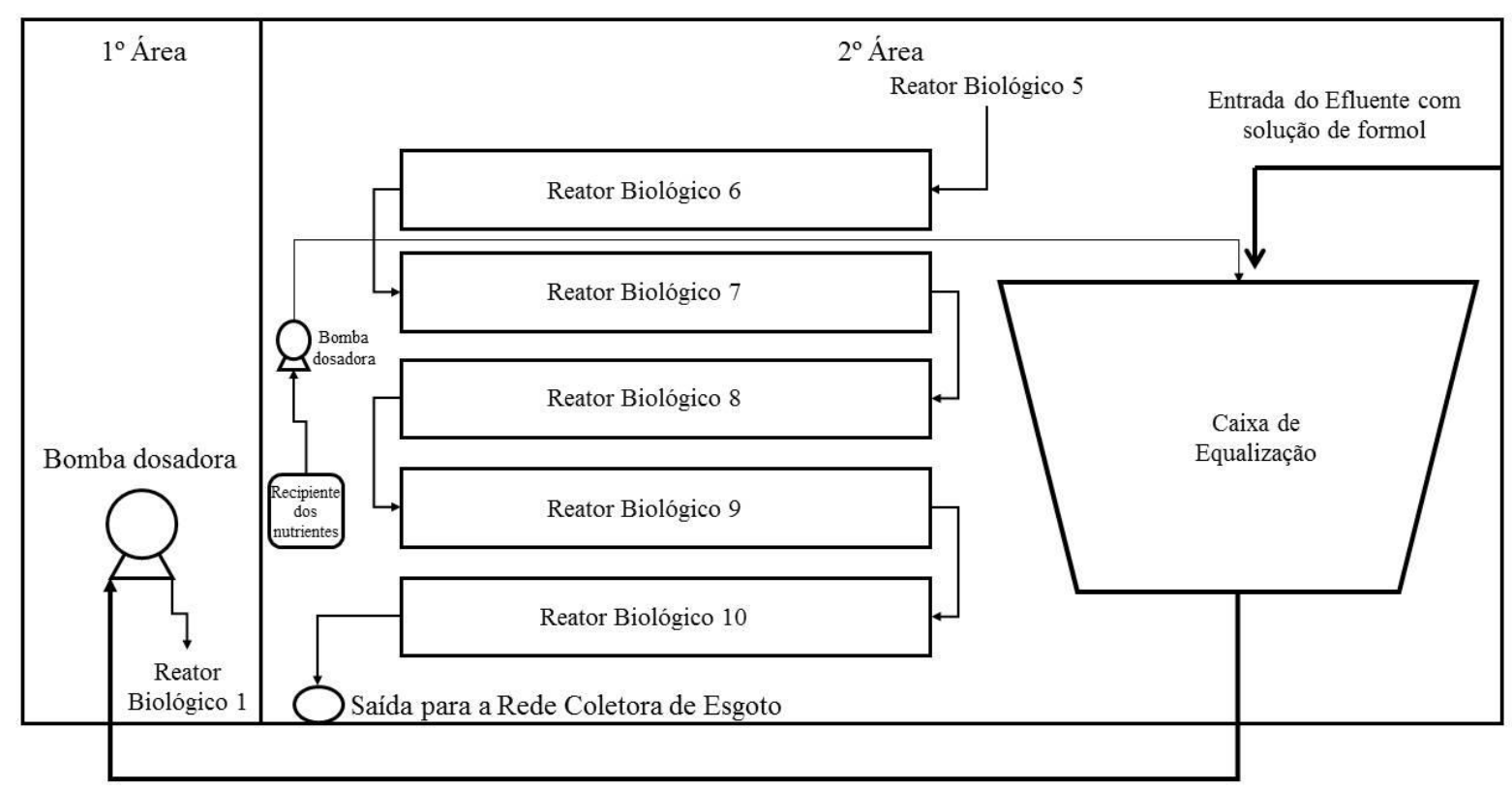

Figura 5- Esquema da vista lateral do RAHLF para o tratamento do efluente contendo formol gerado na EERP/USP. 


\subsection{Amostragem}

Para o presente estudo, foram selecionados dois pontos de coleta, sendo a entrada e saída do Biodigestor. (Figura 6)

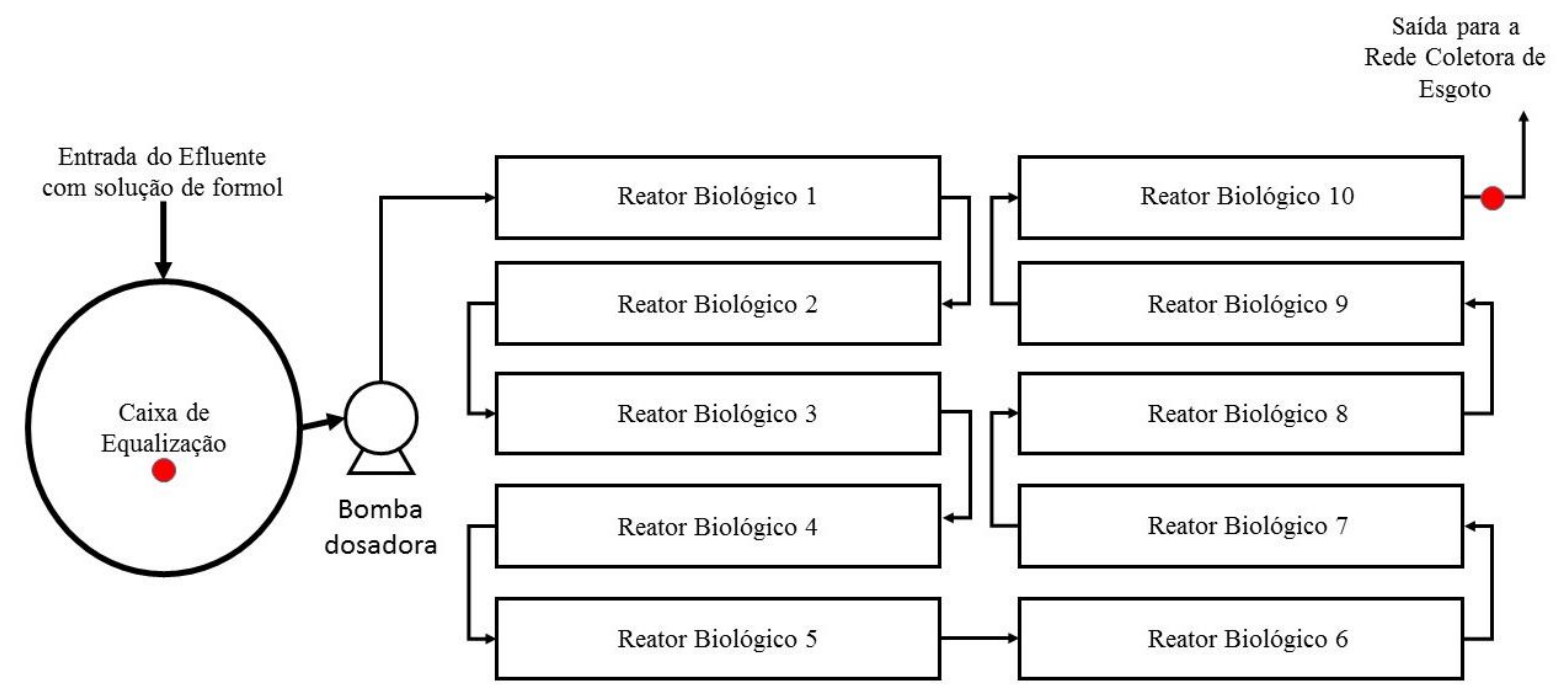

Ponto de Coleta de Amostra

Figura 6- Esquema do RAHLF para o tratamento do efluente contendo formol gerado na EERP/USP com os pontos de coleta de amostra.

Foram coletadas quatro amostras consecutivas de cada ponto de coleta e acondicionadas em frasco de vidro transparente de boro silicato com capacidade de $250 \mathrm{~mL}$ e rotulados. Tais frascos foram preenchidos sem que houvesse a presença de ar após o seu fechamento, evitando a possível oxidação e volatilização do produto presente na amostra. Imediatamente, foram transportados para o Laboratório Multidisciplinar da EERP/USP para conduzir as análises.

O ano de 2020 teve seu início marcado por novas conjecturas em virtude das condições epidemiológicas provocadas pelo SARS-CoV-2 com a consequente pandemia de Covid-19. Diante desse cenário, com a suspensão das atividades presenciais e a implantação do ensino remoto apenas as amostras do efluente gerado no Laboratório Multidisciplinar identificadas como A3, A4, A5 e A6, foram resultados da diluição das peças cadavéricas. Portanto, para as demais amostras e visando assegurar o contínuo funcionamento do sistema de tratamento, foi preparada uma solução à base de formol à 37\%, com concentração final de $500 \mathrm{mg} . \mathrm{L}^{-1} \mathrm{em}$ um volume de 1000 litros. 
Para averiguar a eficiência do RAHLF, foram realizadas as coletas em dois momentos, primeiro no envio do efluente gerado ou preparado no Laboratório Multidisciplinar, ou seja, preenchimento da Caixa de Equalização. E o segundo momento de coleta compreendeu o período de esvaziamento completo da Caixa de Equalização, resultando em um intervalo de sete dias entre os momentos. As coletas ocorreram no período de 10 de fevereiro a 01 de junho de 2020 e 07 de setembro a 09 de novembro de 2020 totalizando 27 semanas.

\subsection{Suprimentos nutricionais para os biorreatores}

Conforme Oliveira 2001, no desenvolvimento e validação do protótipo do RAHLF, deve-se fornecer o Meio Angelidaki, que consiste de um suprimento nutricional para adequação das condições ambientais para a sobrevida das bactérias nos biorreatores (ANGELIDAKI et al, 1990). Estes suprimentos foram definidos e dimensionados pela autora do protótipo, não sendo alvo deste estudo. Tais suprimentos nutricionais foram preparados semanalmente e com uso imediato, utilizando os componentes químicos para análises (P.A) destacados no quadro (1) abaixo.

Quadro 1 Composição de nutrientes e tamponamento para a solução do meio Angelidaki

\begin{tabular}{|l|c|}
\hline \multicolumn{1}{|c|}{ Componentes } & $\begin{array}{c}\text { Quantidade em gramas para a } \\
\text { solução de 10 litros. }\end{array}$ \\
\hline Bicarbonato de Sódio P.A. & 328,13 \\
Cloreto de Cálcio Anidro P.A. & 77,11 \\
Cloreto de Cobalto II (oso) P.A. ACS & 0,13 \\
Cloreto de Ferro III (ico) Anidro P.A & 0,82 \\
Dióxido de Selênio & 0,11 \\
Fosfato de Potássio Bibásico Anidro P.A. ACS & 35,60 \\
Fosfato de Potássio Monobásico Anidro P.A. ACS & 139,45 \\
Fosfato de Sódio Bibásico Anidro P.A. ACS & 54,80 \\
Sulfato de Ferro II (oso) P.A. ACS & 8,20 \\
Sulfato de Níquel (oso) P.A. & 1,64 \\
Uréia (carbamida) P.A ACS & 205,08 \\
\hline
\end{tabular}




\subsection{Métodos Analíticos}

Durante os experimentos foram monitorados $\mathrm{pH}$, temperatura e a Concentração de formol.

\subsubsection{Análise de $\mathrm{pH}$ e Temperatura}

As análises para aferição de pH e temperatura foram realizadas imediatamente após a coleta de amostras e simultaneamente nos dois pontos selecionados, utilizando o equipamento Marconi modelo PA200.

\subsubsection{Quantificação do formol presente nas amostras}

Para a quantificação das concentrações do formol nas soluções, tanto do efluente quanto do afluente, foi adotado o método colorimétrico de Bailey \& Rankin (1971). As soluções tampão de fosfato dissódico-ácido cítrico (Solução de Mcllvaine) de pH 5,6 (Assumpção \& Morita, 1968) e solução $1 \%$ de dicloreto de p-fenilenodiamina $\left(\mathrm{C}_{6} \mathrm{H}_{8} \mathrm{~N}_{2} .2 \mathrm{HCl}\right)$ foram preparadas previamente ao desenvolvimento do método da análise. O Peróxido de Hidrogênio $\left(\mathrm{H}_{2} \mathrm{O}_{2}\right)$ foi adquirido em qualidade P.A. e mantido em refrigeração com temperatura de aproximadamente $6^{\circ} \mathrm{C}$.

\subsubsection{Preparação da solução tampão de fosfato dissódico-ácido cítrico de pH 5,6}

A solução tampão de fosfato dissódico-ácido cítrico foi preparada a partir da homogeneização e dissolução de 8,824g de ácido cítrico $\left(\mathrm{C}_{6} \mathrm{H}_{8} \mathrm{O}_{7}\right)$ e 20,665g de fosfato de sódio bibásico $\left(\mathrm{Na}_{2} \mathrm{HPO}_{4}\right)$ em $1000 \mathrm{~mL}$ de água destilada, posteriormente armazenada em frasco âmbar de 1L e conservada em refrigeração.

\subsubsection{Reagente $1 \%$ de dicloreto de p-fenilenodiamina $\left(\mathrm{C}_{6} \mathrm{H}_{8} \mathrm{~N}_{2} .2 \mathrm{HCl}\right)$}

Previamente ao preparo da solução de $1 \%$ de dicloreto de p-fenilenodiamina $\left(\mathrm{C}_{6} \mathrm{H}_{8} \mathrm{~N}_{2} .2 \mathrm{HCl}\right)$ foi necessária uma etapa adicional de purificação do composto, em decorrência do processo de oxidação sofrido pelo reagente, que estava apresentando a coloração castanho escuro. Tal etapa de purificação foi conduzida através da cristalização a 
partir da solução diluída e aquecida a $60^{\circ} \mathrm{C}$ de $2 \mathrm{~g}$ de dicloreto p-fenilenodiamina em $120 \mathrm{~mL}$ de Ácido Clorídrico P.A. (HCl) acrescidos de $80 \mathrm{~mL}$ de água destilada. Após a sua dissolução, foram adicionados $4 \mathrm{~g}$ de Cloreto de Estanho II $\left(\mathrm{SnCl}_{2}\right)$, carvão ativado e igual volume de Ácido Clorídrico P.A. ( $\mathrm{HCl})$, e com o uso do método à vácuo filtrou-se esta solução em papel filtro quantitativo médio e resfriando-se em banho de gelo e álcool. Os cristais formados foram filtrados em papel filtro quantitativo e secados a vácuo, em dissecador, sobre Gel de sílica e Hidróxido de Sódio $(\mathrm{NaOH})$. Após um período de 48 horas no dissecador, os cristais estavam disponíveis para o preparo da solução. Visando manter a qualidade da solução e evitar a oxidação, esta foi preparada apenas durante o desenvolvimento do método através da dissolução de $0,100 \mathrm{~g}$ do composto purificado em um volume de $10 \mathrm{~mL}$ de água destilada.

\subsubsection{Curva de Calibração}

Para o desenvolvimento do método proposto, foi realizado o preparo prévio da curva de calibração (Figura 7) para as concentrações de $1 \mathrm{mg} . \mathrm{L}^{-1}$ a $3,5 \mathrm{mg} . \mathrm{L}^{-1}$ com intervalos de 0,5 mg.L $L^{-1}$ entre eles. Foram preparadas várias curvas de calibração durante a evolução dos experimentos, sempre que houvesse a substituição de um dos três reagentes citados anteriormente.

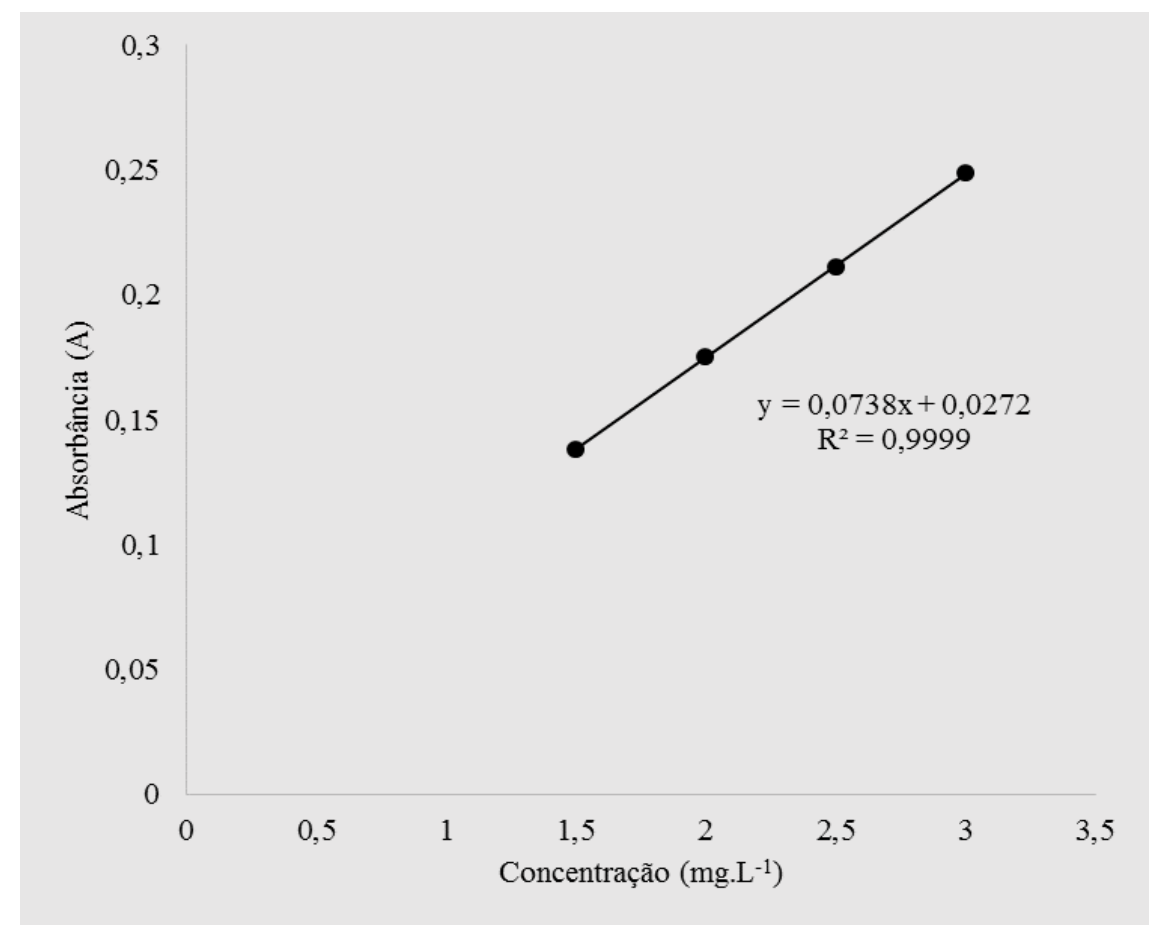

Figura 7- Curva de Calibração para determinação da concentração do formol pelo método de Bailey \& Rankin, 1971. 


\subsubsection{Método colorimétrico de Bailey e Rankin (1971)}

Para o procedimento de análise das concentrações de formol pelo método adotado foi necessário fazer diluições para que as amostras tivessem resultados nas faixas de concentrações da curva de calibração. Em balões volumétricos de $100 \mathrm{~mL}$, adicionou-se os três reagentes na seguinte ordem: 10mL da solução tampão dissódico-ácido cítrico pH 5,6, $1 \mathrm{~mL}$ da solução de $1 \%$ de dicloreto de p-fenilenodiamina e $5 \mathrm{~mL}$ de peróxido de hidrogênio P.A., completando o volume do balão com água destilada. No laboratório optou-se por trabalhar com balões de $25 \mathrm{~mL}$ utilizando-se um quarto (1/4) do volume dos reagentes mencionados. Para realização da leitura, foi necessário após a adição do terceiro reagente cronometrar o tempo de 20 minutos mantendo a solução tampada e em repouso. Dessa forma, foi possível garantir a repetibilidade para o tempo em todas as amostras, considerando que não há robustez para o tempo. A leitura foi realizada no espectrofotômetro Boeco modelo S$22 \mathrm{UV} / \mathrm{Vis}$, com cubeta de quartzo de $10 \mathrm{~mm}$, no comprimento de onda de 420nm. Em todos os ensaios, o aparelho espectrofotômetro foi calibrado com uma solução Branco preparada com água destilada e, posteriormente, seguiu-se o tempo 20 minutos para a leitura

\subsection{Mapeamento dos pontos críticos do processo de tratamento do efluente contendo formol}

Todas as fases relacionadas com uso e geração de resíduo contendo formol no Laboratório Multidisciplinar foram mapeadas em fluxogramas. Dessa forma, com o descritivo da atividade realizada em cada etapa, foram apontados os pontos críticos de controle com observações criteriosas a fim de garantir o adequado funcionamento do sistema e a eficiência da degradação do formol até o lançamento do efluente na rede de coleta do Campus.

\subsubsection{Mapeamento do processo}

Diante do exposto, neste estudo elaboramos um fluxograma para o mapeamento do processo de tratamento dos efluentes. Após a divisão, os setores foram registrados e analisados os processos e atividades em cada etapa. Através do uso de simbologia representativa para sistemas de tratamento de efluentes, foi possível mapear desde a Sala para 
Conservação das Peças Cadavéricas até o lançamento dos efluentes na rede coletora de esgoto municipal.

\subsubsection{Identificação dos pontos críticos do processo}

A partir do fluxograma, foram avaliados qualitativamente os pontos críticos do processo em quatro sub-etapas: determinação dos setores críticos; identificação dos pontos críticos; determinação dos potenciais de falha; e avaliação dos pontos críticos. Para a determinação dos setores responsáveis pelos maiores riscos durante o processamento do efluente contendo formol, será utilizada a metodologia FMEA, adaptada de Stamatis (1995).

Para isso, cada setor será classificado quanto à ocorrência $(\mathrm{Oc})$, severidade $(\mathrm{Sv})$ e detecção (Dt) de falhas em escala de 1 a 5 (Tabela 1). Os índices utilizados e os critérios de classificação foram elaborados e adaptados para o presente estudo seguindo como guia a proposta de Matos e Milan (2009).

Tabela 1- Critérios utilizados da FMEA para identificação dos índices de ocorrência, severidade e detecção de falhas no processo de tratamento de efluentes contendo formol do Laboratório Multidisciplinar da EERP/USP.

\begin{tabular}{|c|c|c|c|}
\hline Índices & \multicolumn{3}{|c|}{ Critérios da FMEA } \\
\hline & Ocorrência (Oc) & Severidade $(\mathrm{Sv})$ & Detecção (Dt) \\
\hline 1 & $\begin{array}{l}\text { Probabilidade muito remota de } \\
\text { acontecer falha }\end{array}$ & Falha quase imperceptível & $\begin{array}{l}\text { Probabilidade muito alta } \\
\text { de detectar a falha }\end{array}$ \\
\hline 2 & Baixa ocorrência de falhas & $\begin{array}{l}\text { A falha é percebida, sem afetar o } \\
\text { processo }\end{array}$ & $\begin{array}{l}\text { Probabilidade alta de } \\
\text { detectar a falha }\end{array}$ \\
\hline 3 & Moderada ocorrência de falhas & $\begin{array}{l}\text { A falha é percebida e afeta } \\
\text { minimamente o processo }\end{array}$ & $\begin{array}{l}\text { Probabilidade média de } \\
\text { detectar a falha }\end{array}$ \\
\hline 4 & Alta ocorrência de falhas & $\begin{array}{l}\text { A falha é percebida e afeta o } \\
\text { processo sem quebra da segurança }\end{array}$ & $\begin{array}{l}\text { Probabilidade baixa de } \\
\text { detectar a falha }\end{array}$ \\
\hline 5 & $\begin{array}{l}\text { Alarmante ocorrência } \\
\text { falhas }\end{array}$ & $\begin{array}{l}\text { A falha é percebida, e afeta o } \\
\text { processo com quebra da } \\
\text { segurança. }\end{array}$ & $\begin{array}{l}\text { Probabilidade muito } \\
\text { baixa de detectar a falha }\end{array}$ \\
\hline
\end{tabular}

Adaptada de Stamatis, 1995

A partir dos valores atribuídos a cada critério, o índice de risco (IR) será calculado pela equação:

$\mathrm{IR}=\mathrm{Oc} \times \mathrm{Sv} \times \mathrm{Dt}$

Em que:

Oc=índice de ocorrência;

$\mathrm{Sv}=$ índice de severidade;

$\mathrm{Dt}=$ índice de detecção. 
Com isso, as etapas do processo de tratamento de efluentes contendo formol do laboratório serão classificados quanto ao seu potencial de risco, com base no maior índice (IR). 


\section{RESULTADOS E DISCUSSÃO}

\subsection{Avaliação do desempenho do RAHLF, com determinação das concentrações da solução de formol no afluente e efluente do sistema.}

Diferentes métodos, sejam eles químicos ou biológicos, podem ser utilizados para promover o tratamento prévio ao descarte de soluções contendo formol. Dentre os métodos químicos destacam-se os Processos Oxidativos Avançados (POAs), como por exemplo a degradação através do Processo Foto-Fenton, cujo mecanismo é baseado na geração de radicais hidroxila $(\mathrm{OH})$, em meio ácido, ocasionando degradação de moléculas orgânicas, tais como o formaldeído. Como resultado deste processo, ocorre a produção de dióxido de carbono $\left(\mathrm{CO}_{2}\right)$ e água $\left(\mathrm{H}_{2} \mathrm{O}\right)$, substâncias estas com menor impacto ao meio ambiente. Como exemplo de tratamentos biológicos, cita-se o uso de reatores anaeróbios como o RAHLF, cujas importantes características incluem a possibilidade de tratamento de grandes volumes de resíduos, bem como reduzido custo do processo e menor exposição ocupacional.

Embora existam diferentes pesquisas sobre o tratamento anaeróbio das águas residuárias contendo formol (VIDAL et al., 1999; OLIVEIRA, 2001), em sua maioria os estudos basearam-se no uso de reatores anaeróbios em modelo de bancada. No ano de 2008, o Hospital das Clínicas de Ribeirão Preto (HC/FMRP/USP) implantou um RAHLF, utilizado para o tratamento das águas residuárias contendo formol, geradas em laboratórios do hospital, porém não existem dados na literatura quanto ao monitoramento da eficiência deste reator. Portanto, neste estudo inédito em escala industrial, além de monitorar a eficiência da remoção da solução de formol dos efluentes gerados no sistema também mapeamos e caracterizamos os pontos críticos de controle do processo de tratamento do biodigestor anaeróbio de resíduo de formol.

Como descrito previamente, no preparo das aulas práticas de anatomia, as peças cadavéricas eram removidas dos tanques contendo solução de formol com cerca de 48 horas de antecedência das atividades práticas, sendo imersas em tanque de diluição preenchido totalmente com água. Tal processo de diluição visa diminuir a concentração de formol nas peças cadavéricas e consequentemente o nível de exposição dos usuários a este composto. Visto que o efluente gerado apresenta concentrações elevadas de formol (OLIVEIRA, 2001), não é permitido o descarte desta solução na rede coletora de esgotos sem tratamento prévio, diante da toxicidade da mesma. Nossos resultados confirmam o descrito, visto que as 
concentrações obtidas de formol no afluente do RAHLF variaram de 238,37 a 774,60 mg.L -1 $^{-1}$ (Tabela 2 e Figura 8).

Todo efluente gerado pelo Laboratório Multidisciplinar foi enviado para a Caixa de Equalização, que possui registro de saída, para possível manutenção necessária, possibilitando dessa forma o controle do envio do afluente para os biorreatores. Como descrito previamente, neste estudo a caixa de Equalização foi o primeiro ponto de coleta, sendo definido como entrada do reator.

A Tabela 2 e a Figura 8 demonstram as concentrações médias de formol (mg. $\left.\mathrm{L}^{-1}\right)$ em amostras obtidas da Caixa de Equalização do sistema de tratamento implantado, obtidos durante o período de análise. Como descrito previamente, em virtude da Pandemia de Covid19 e das restrições de circulação impostas, com a suspensão das aulas práticas da disciplina de Anatomia, foram utilizadas duas estratégias para alimentação do reator. Durante o período de atividades práticas, foi fornecido ao sistema as águas residuárias contendo formol após a submersão das peças cadavéricas no tanque de diluição. Durante o período de ausência de aulas práticas, semanalmente foi gerado um volume de $1000 \mathrm{~L}$ de efluente contendo formol, como demonstrado na tabela 2 e figura 8 , resultando em uma concentração média de formol de 480,19 $\pm 116,06 \mathrm{mg} . \mathrm{L}^{-1}$. Dessa forma, este efluente foi encaminhado para o sistema de tratamento implantado na EERP/USP. 
Tabela 2 Distribuição das concentrações médias de formol (mg. $\left.L^{-1}\right)$ das amostras coletadas do afluente e efluente do sistema de tratamento (RAHLF) da EERP/USP, no periodo de fevereiro a junho e de setembro a novembro de 2020.

\begin{tabular}{|c|c|c|}
\hline Amostras & $\begin{array}{c}\text { Concentração de formol } \\
\text { no afluente do RAHLF } \\
\left(\mathrm{mg} \cdot \mathrm{L}^{-1}\right)\end{array}$ & $\begin{array}{l}\text { Concentração de formol } \\
\text { no efluente do RAHLF } \\
\left(\mathrm{mg} \cdot \mathrm{L}^{-1}\right)\end{array}$ \\
\hline A1 & 438,44 & 1,37 \\
\hline $\mathrm{A} 2$ & 429,73 & 1,86 \\
\hline $\mathrm{A} 3$ & 496,70 & 1,11 \\
\hline A4 & 774,60 & 1,12 \\
\hline A5 & 274,77 & 1,44 \\
\hline A6 & 460,96 & 2,32 \\
\hline A7 & 485,28 & 0,91 \\
\hline A8 & 427,03 & 0,86 \\
\hline A9 & 459,76 & 1,16 \\
\hline A10 & 464,86 & 2,04 \\
\hline A11 & 427,14 & 2,08 \\
\hline A12 & 436,01 & 1,84 \\
\hline A13 & 602,76 & 1,94 \\
\hline A14 & 481,66 & 1,77 \\
\hline A15 & 491,17 & 1,79 \\
\hline A16 & 547,47 & 0,04 \\
\hline A17 & 556,98 & 0,40 \\
\hline A18 & 524,64 & 1,17 \\
\hline A19 & 539,86 & 0,94 \\
\hline A 20 & 326,24 & 1,38 \\
\hline $\mathrm{A} 21$ & 343,01 & 1,23 \\
\hline A 22 & 238,37 & 1,17 \\
\hline A 23 & 406,53 & 0,79 \\
\hline A 24 & 441,28 & 2,08 \\
\hline A 25 & 596,11 & 1,99 \\
\hline A26 & 652,99 & 1,65 \\
\hline $\mathrm{A} 27$ & 640,88 & 1,06 \\
\hline Média & 480,19 & 1,39 \\
\hline Desvio Padrão & 116,06 & 0,56 \\
\hline Valor Mínimo & 238,37 & 0,04 \\
\hline Valor Máximo & 774,60 & 2,32 \\
\hline
\end{tabular}

Fonte: Própria

Diante das elevadas concentrações de formol presentes no efluente gerado no Laboratório Multidisciplinar, os volumes gerados apenas foram encaminhados para o sistema de reatores após comprovada a eficiência dos mesmos. A coleta foi realizada após a passagem 
do efluente no último reator. A tabela 2 e a figura 8 demonstram as concentrações de formol obtidas no efluente do sistema de tratamento, cujo valor médio foi de 1,39 $\pm 0,56 \mathrm{mg} . \mathrm{L}^{-1}$, demonstrando em nossos estudos que a eficiência na degradação do formol pelo RAHLF foi em média de $99,70 \%$.

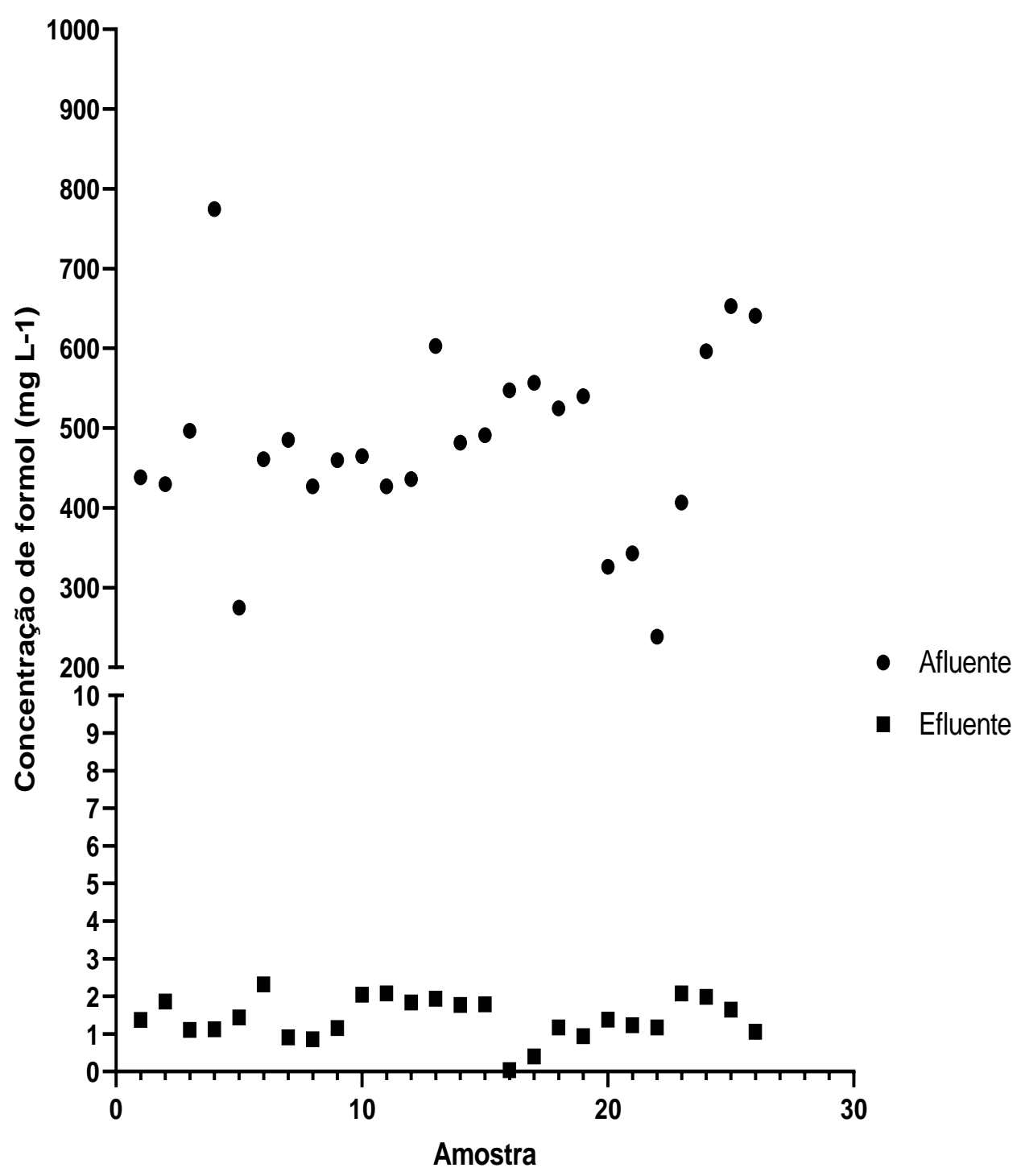

Figura 8- Concentrações médias de formol $\left(\mathrm{mg} \mathrm{L}^{-1}\right)$, no afluente e efluente do RAHLF da EERP/USP, obtidas através de método colorimétrico, durante o período de análise.

Estudos prévios de Zoutberg e De Been (1997), utilizando modelo de bancada, demonstraram que no sistema RAHLF quando a concentração de formol no afluente era de $333 \mathrm{mg} . \mathrm{L}^{-1}$ de formol, as concentrações do composto obtidas no efluente eram menores que 
$20 \mathrm{mg} . \mathrm{L}^{-1}$, embora os autores não tenham avaliado o comportamento do sistema com concentrações de afluentes superiores ao descrito.

Por outro lado, estudos de Vidal e colaboradores (1999) demonstraram que aumentos nas concentrações de formol, atingindo valores de até $950 \mathrm{mg} \cdot \mathrm{L}^{-1}$ não resultaram em impactos nas concentrações deste composto nos efluentes. Qu \& Bhattacharya (1997) ao estudarem a eficiência do reator utilizando concentrações elevadas de formol nos afluentes $\left(1110 \mathrm{mg} . \mathrm{L}^{-1}\right)$ identificaram que as concentrações deste composto no efluente foram menores que $1 \mathrm{mg} . \mathrm{L}^{-1}$. Corroborando os trabalhos acima descritos, evidenciamos em nossos estudos que a elevação nas concentrações do formol nos afluentes gerados, alcançando níveis de 774,60 mg.L $\mathrm{L}^{-1}$, foram acompanhadas de manutenção na eficiência do RAHLF, com concentrações do composto de $1,12 \mathrm{mg} . \mathrm{L}^{-1}$ obtidas na análise dos efluentes gerados. A eficiente degradação do formol faz se necessária, visto que concentrações de $5 \mathrm{mg} . \mathrm{L}^{-1}$ desta substância já apresentam toxicidade para diferentes espécies de organismos (GONZALEZ-GIL et al., 2002). Em nossos estudos não avaliamos o comportamento do sistema frente às concentrações acima das citadas, visto que a concentração de formol nas águas residuárias geradas durante a rotina de atividades práticas no Laboratório Multidisciplinar não ultrapassaram tal valor.

$\mathrm{Na}$ figura 9, as análises do $\mathrm{pH}$ no afluente e efluente não apresentaram grandes variações durante o período do estudo. Nossa hipótese, é de que os ácidos produzidos ao longo do processo de degradação não ocasionem alteração no sistema de biorreatores em decorrência da inclusão dos suprimentos nutricionais no afluente.

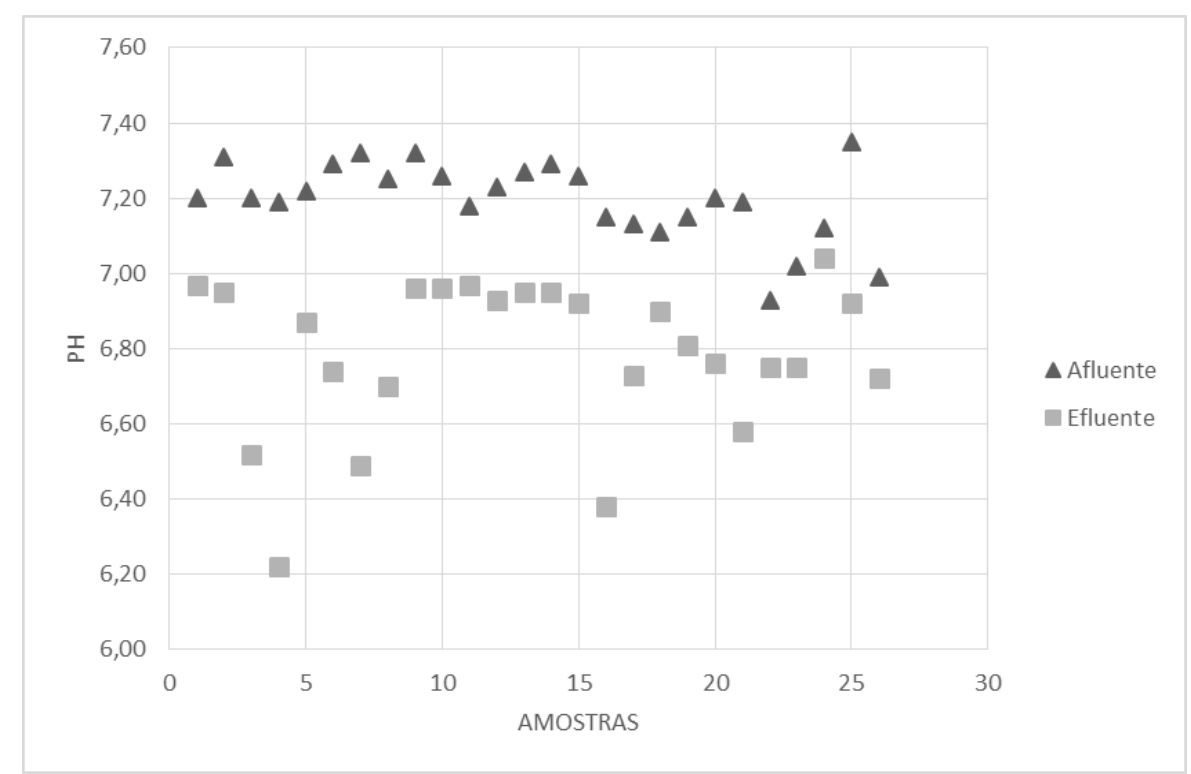

Figura 9- Distribuição dos dados de pH das amostras do afluente e efluente do RAHLF da EERP/USP, no período de fevereiro a junho e de setembro a novembro de 2020. 


\subsection{Mapeamento e identificação dos pontos críticos do processo de tratamento de efluentes contendo formol}

Diante do uso da solução de formol na conservação de cadáveres, essencial para as atividades de ensino da disciplina de anatomia humana, e com o objetivo de minimizar os impactos causados pelo descarte de soluções de formol no meio ambiente, no presente estudo, todas as fases relacionadas com uso e geração de resíduo contendo esse composto foram mapeadas.

É importante destacar que desde 1949 a metodologia FMEA tem sido amplamente utilizada e em diferentes áreas do conhecimento. E com sua aplicação é possível identificar pontos potencialmente suscetíveis a falha, permitindo dessa forma o desenvolvimento de ações para eliminar ou reduzir tais ocorrências (SCHMITT, 2013).

Considerando que para o mapeamento é imprescindível o conhecimento de todas as atividades que constituem os processos essenciais, em nosso estudo os setores foram divididos, registrados e analisados os processos e atividades em cada etapa, desde a geração do resíduo até o lançamento do efluente na rede de coletora do Campus.

\subsubsection{Local Gerador}

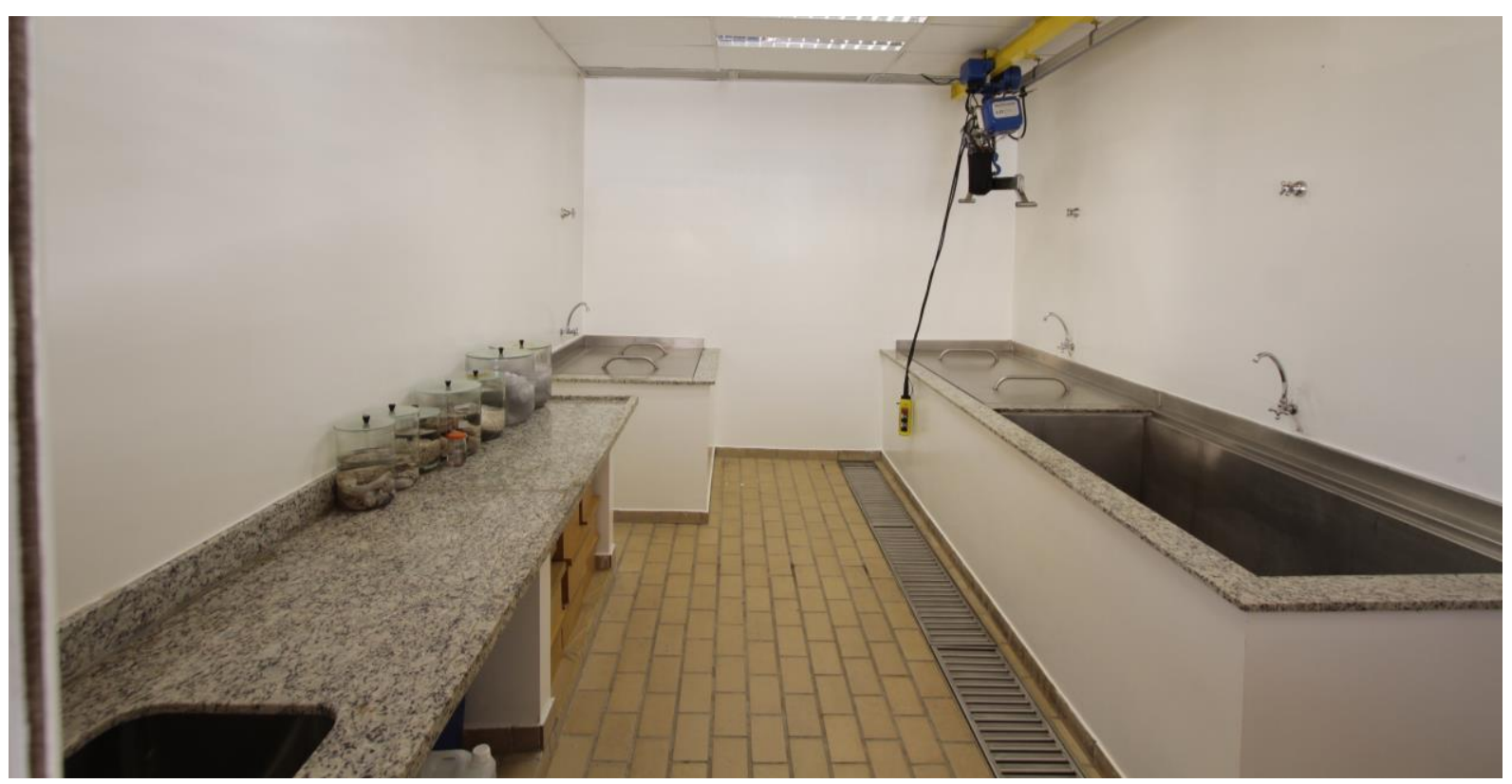

Figura 10- Sala para Conservação das Peças Cadavéricas (Local Gerador) 
A Sala para Conservação das Peças Cadavéricas (Figura 10) é composta de três tanques, sendo que dois deles (Tanques 1 e 2) comportam a solução de formol, e o tanque 3 é destinado para diluição e submersão das peças cadavéricas em água. Tais tanques possuem registros independentes os quais enviam o afluente presente para o sistema coletor. De 2011 até 2017 houve a implantação da coleta dos efluentes dos tanques mencionados para a Caixa Intermediária, cuja função era diluição destes efluentes para que pudesse ser destinado para a rede coletora municipal de esgoto, entretanto nunca foi utilizado.

Após a readequações e reforma, que ocorreram em 2017, houve uma reformulação nos procedimentos laboratoriais executados pelos técnicos responsáveis. A primeira foi a não disposição do efluente com formol na pia presente na sala, destinada unicamente para a limpeza do material utilizado. É importante salientar que após a reestruturação do laboratório, o encanamento de coleta presente foi direcionado diretamente para rede coletora de esgoto municipal, não havendo a possibilidade de resgaste do líquido enviado.

A partir da definição das etapas do processo, identificou-se a importância da não disposição da solução de formol presente nos Tanques Internos 1 e 2, tanto para o sistema de tratamento quanto para a rede coletora de esgoto municipal. Os dados da tabela 3 evidenciam o comprometimento da eficiência do sistema de tratamento na degradação do formol presente nestas soluções, como consequente prejuízo ao seu funcionamento.

Tabela 3 Distribuição das concentrações da solução enviada para o RAHLF da EERP/USP e a sua eficiência ocorrida nos dias 09 e 16 de dezembro 2019.

\begin{tabular}{l|c|c|c}
\hline Local Gerador & $\begin{array}{c}\text { Concentração na Entrada } \\
\text { do Biodigestor }\left(\mathrm{mg} \cdot \mathrm{L}^{-1}\right)\end{array}$ & $\begin{array}{c}\text { Concentração na Saída } \\
\text { do Biodigestor }\left(\mathrm{mg} \cdot \mathrm{L}^{-1}\right)\end{array}$ & $\begin{array}{c}\text { Degradação Ocorrida } \\
\text { pelo Biodigestor (\%) }\end{array}$ \\
\hline Tanque Interno 1 & $10.477,72$ & $9.487,92$ & 9,45 \\
\hline Tanque Interno 2 & $5.748,73$ & $4.082,13$ & 28,99 \\
\hline
\end{tabular}

Fonte: Própria

No Tanque Interno 3, pode ocorrer geração de efluente contendo soluções de detergente, utilizado para limpeza do tanque, ou contendo água com solução de formol proveniente das peças cadavéricas. Diante disso, foi necessária a implantação da Caixa de Registro na interligação do local gerador com o sistema de tratamento, cuja função é a destinação correta do efluente gerado por este tanque.

Outra etapa importante avaliada foi no ponto de coleta na grelha de piso, que apresenta ligação direta com o encanamento dos tanques. Utilizando o método analítico para 
detecção de potencial de risco e dessa forma elaborar o plano de ação para o bloqueio de falhas, orientando-se pelo novo protocolo de operação do laboratório, a probabilidade de ocorrer falhas se torna remota, ou seja, índice 1 (um). A severidade apresentou índice 5 (cinco), ou seja, a falha é percebida, sendo ocasionada devido à quebra do protocolo de funcionamento do laboratório, porém não há possibilidade de retorno. Quanto à detecção o índice foi 1(um), em que a falha poderá ser detectada no local (como esgotamento dos tanques internos 1 e 2 e das cubas de vidro).

Multiplicando-se os índices apresentados pelas ocorrências, severidade e detecção, obteve-se o índice de risco 5 (IR=5) da Sala para Conservação de Peças Cadavéricas para cada ponto crítico apresentado.

5.2.2. Interligação dos Tanques da Sala para Conservação de Peças Cadavéricas até o Sistema de Tratamento.

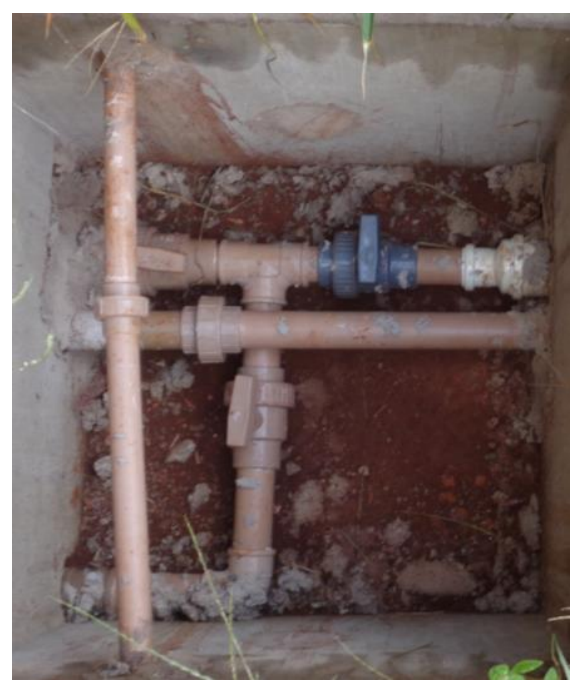

Figura 11- Caixa de Registros 


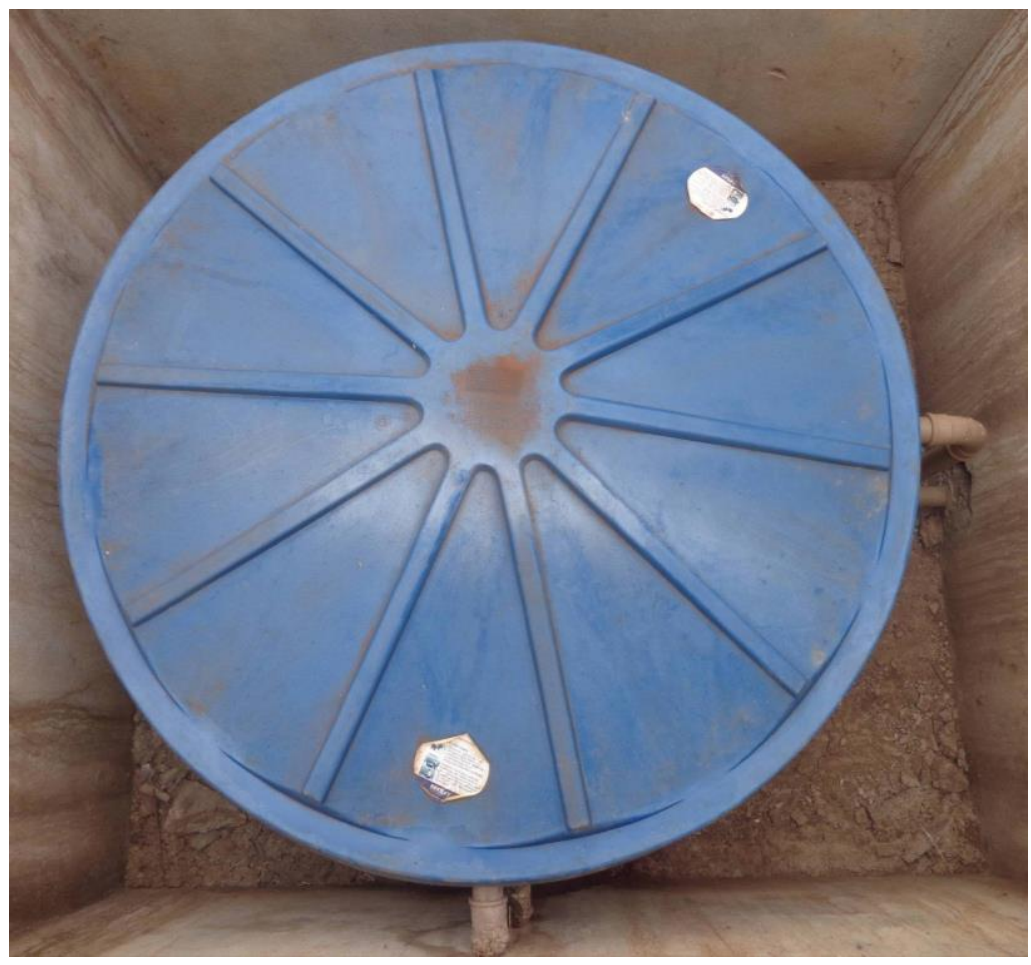

Figura 12- Caixa Intermediária

A Caixa de Registros (Figura 11) deverá ser sempre manuseada seguindo rigorosamente os protocolos do Laboratório Multidisciplinar. A Caixa Intermediária (Figura 12), pelo fato de não armazenar o efluente gerado, não apresentou a necessidade de controle de abertura e fechamento do registro, este sempre mantido aberto.

Entretanto, tanto a Caixa de Registros quanto a Caixa Intermediária apresentam alta possibilidade de ocorrência de falhas, com baixa probabilidade de detecção, somente percebida após a sua ocorrência. Tal intercorrência irá afetar o sistema de tratamento implantado ou até mesmo propiciar o descarte inadequado de resíduos para as vias públicas. Portanto, nessa etapa com o rompimento dos protocolos de segurança, todos os índices resultaram em nível 5 (cinco), com $\mathrm{IR}=125$.

\subsubsection{Reator Anaeróbio Horizontal de Leito Fixo (RAHLF).}

\subsubsection{Caixa de Equalização}




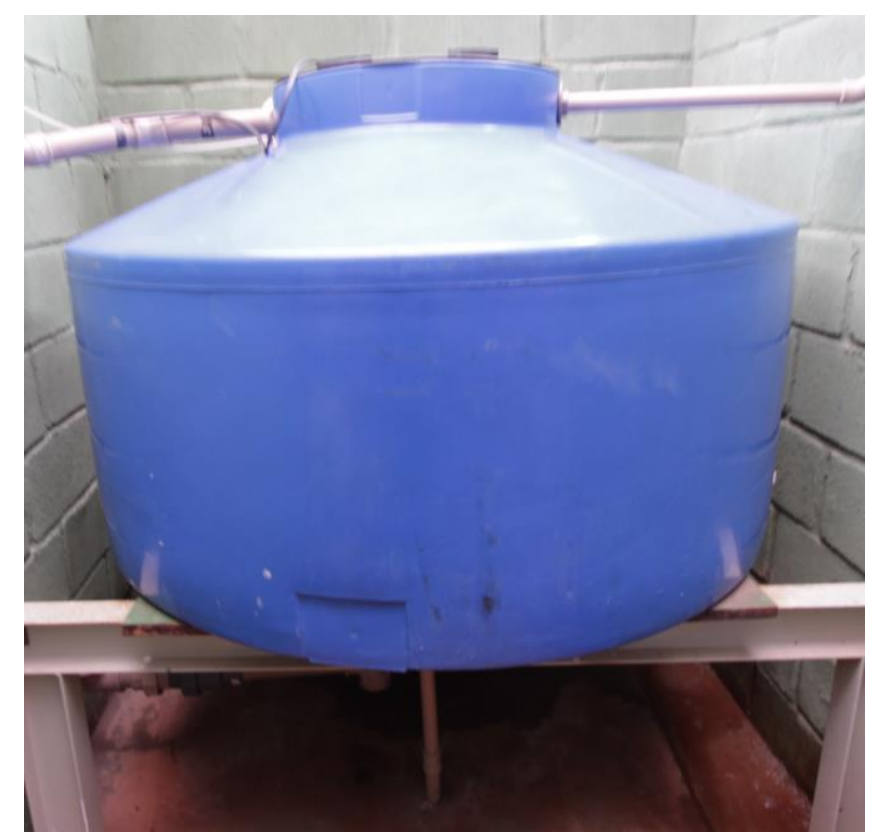

Figura 13 Caixa de Equalização

Todo o efluente gerado pelo Laboratório Multidisciplinar contendo formol é enviado para a Caixa Equalização (Figura 13) que apresenta a função de homogeneização da solução presente. Tal caixa apresenta um registro de saída, para possível manutenção necessária, assim possibilitando o controle do envio de afluente para os biorreatores.

Com a necessidade de fornecimento semanal de resíduo contendo formol, bem como dos suprimentos nutricionais, e pelo fato desta etapa ser composta por uma caixa d'água, torna-se remota a possibilidade de ocorrência de falha (índice é igual a 1), como também é muito alta a probabilidade de se detectar esta (índice é igual 1). Entretanto, neste caso a falha afetará o processo sem ocorrer quebra de segurança (índice é igual 4). Multiplicando-se os índices apresentados obtivemos o índice de risco da Caixa de Equalização é igual a 4 (IR=4)

\subsubsection{Bomba dosadora do Suprimento Nutricional}




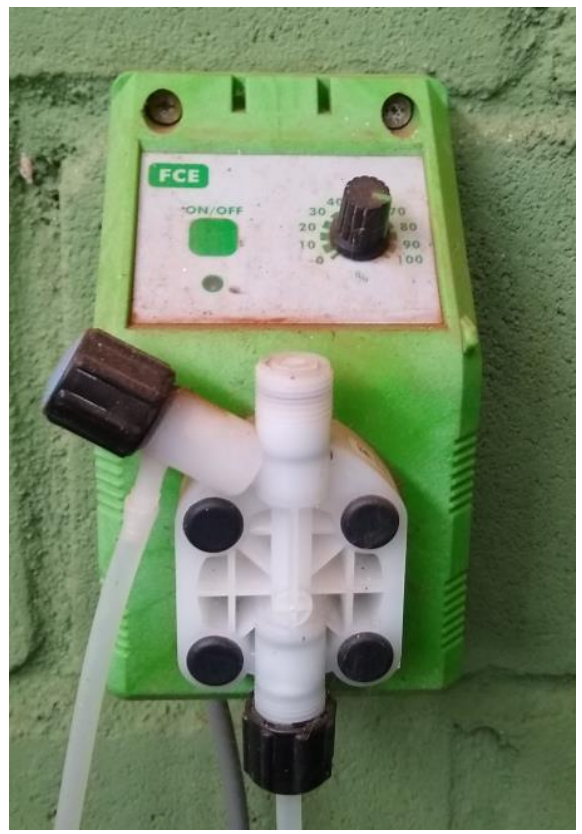

Figura 14- Bomba dosadora da marca FCE modelo FCE 0505

A bomba dosadora (Figura 14) foi implantada no sistema para fornecer o suprimento nutricional diretamente na Caixa Equalização em doses e sem a necessidade de recurso humano para este fim. Entretanto, devido a composição química do suprimento e o tempo para dispor dos nutrientes, de maneira frequente ocorreu a sedimentação deste, e assim, o entupimento da mangueira da bomba, impedindo o seu funcionamento. Diante deste cenário, uma readequação para o fornecimento do suprimento para os biorreatores teve que ser efetuado, passando a ser realizada manualmente. Semanalmente procedeu-se a diluição do suprimento produzido, assegurando a sua completa homogeneização no volume total da Caixa de Equalização. Portanto, o equipamento foi desligado e o processo colocado no protocolo de operação do Laboratório Multidisciplinar.

Como descrito previamente, para manter as colônias de bactérias efetivas dentro dos biorreatores, fez-se necessária a complementação do resíduo contendo formol com suprimentos nutricionais e a sua homogeneização na Caixa de Equalização. Esta etapa sem a bomba dosadora funcional, apresenta uma probabilidade muito remota de acontecer falhas (índice igual a 1). Entretanto, se introduzirmos o equipamento, este alterará para moderada a ocorrência (índice igual 3), visto que o equipamento necessita de eletricidade para o funcionamento e também como descrito anteriormente a composição química do suprimento tende a ocorrer sedimentação com o passar do tempo, provocando o entupimento das mangueiras e a interrupção no funcionamento deste. 
Já o critério da severidade, tanto com a presença do equipamento quanto com o recurso humano com protocolo do laboratório, a falha é percebida podendo não afetar o processo de degradação (índice igual a 2). Porém, caso ocorram falhas consecutivamente o índice poderá aumentar dependendo do número de falhas.

Diante do fornecimento rotineiro e semanal de suprimentos a probabilidade torna alta para detectar qualquer falha possível (índice igual a 1), tanto com a presença do equipamento quanto com o recurso humano.

Multiplicando-se os índices apresentados, resultará em um índice de risco igual a 2 $(I R=2)$ utilizando o recurso humano, já com a presença do equipamento este índice passará para $6(\mathrm{IR}=6)$.

\subsubsection{Bomba Dosadora do Afluente}

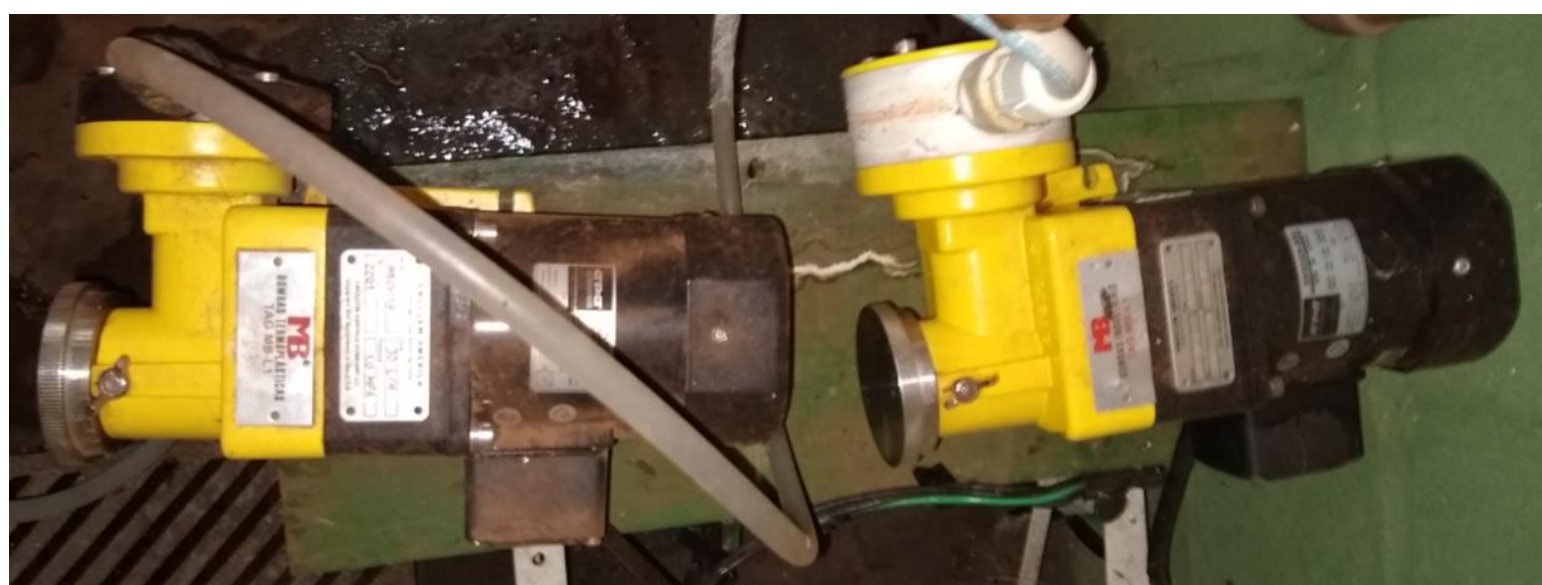

Figura 15 Bomba dosadora de modelo JBB25/1.0

A implantação da bomba dosadora com fluxo $30 \mathrm{~L} / \mathrm{h}$ e força de 1.0 MPA (Figura 15) foi necessária em virtude do recalque do afluente presente na Caixa de Equalização para os biorreatores, visto que estão localizados no mesmo nível é necessária uma força para que o líquido possa circular nas tubulações e ser destinado para a rede coletora municipal. Em virtude do uso da rede elétrica, deve-se constantemente realizar a vistoria deste equipamento, para que em caso, de mal funcionamento ou mesmo para manutenção, a bomba reserva disponível seja acionada, visto que os biorreatores necessitam de suprimentos constantes para o seu adequado funcionamento.

Durante o período de análises, detectou-se a necessidade de implantação de filtros antes da entrada do afluente para a bomba, em decorrência da formação de detritos na Caixa de Equalização. No período de junho a agosto de 2020, identificamos que as bombas 
dosadoras apresentaram um comprometimento funcional e realizamos a manutenção no equipamento.

Com a necessidade de eletricidade para o funcionamento do equipamento e a não presença de um gerador que manteria fornecimento de energia, pode gerar falhas não percebidas durante os dias em que não houver vistoria técnica. Além do fornecimento do resíduo contendo formol e suprimentos nutricionais, durante o processo de manutenção rotineira, também foi efetuada a limpeza dos pré-filtros implantados, sendo neste momento possível a detecção de falhas existentes. Utilizando os critérios para identificação de ocorrência de falha, classifica-se como índice 3 (três) sendo moderado.

Para o critério de detecção o índice de classificação foi 3(três), em virtude da ausência de vistoria técnica durantes os seis dias da semana. E finalmente o critério da severidade foi classificado com índice 4 (quatro), pois a falha é percebida ocasionalmente afetando o processo, mas sem haver a quebra de segurança.

Multiplicando os índices apresentados obtivemos o IR=36 (trinta e seis).

\subsubsection{Biorreatores}

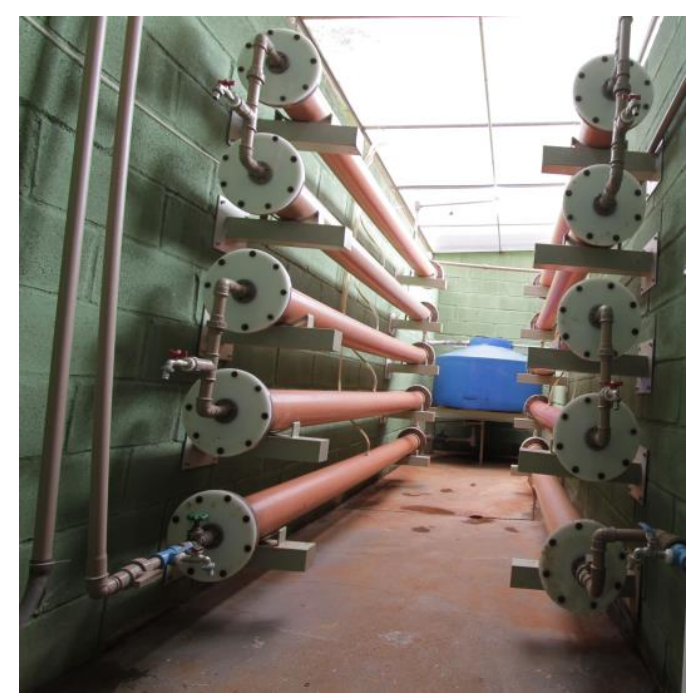

Figura 16- Biorreatores

Como descrito previamente, as dez tubulações de PVC foram preenchidas com cubos de espuma de poliuretano embebidos com lodo, contendo as bactérias que degradam o formol presente no efluente do Laboratório Multidisciplinar. Foram implantadas saídas para o biogás nos tubos e amostradores entre estes. Houve a necessidade da adaptação de pescoço de cisne no encanamento para que ocorresse o preenchimento integral das tubulações com o resíduo. 
Os biorreatores (Figura 16) foram implantados para funcionar em conjunto com a bomba dosadora do afluente e a Caixa de Equalização mencionadas anteriormente, portanto há necessidade da verificação contínua do esvaziamento semanal da Caixa de Equalização, o funcionamento da bomba, e monitoramento da saída do efluente para a rede coletora de esgoto.

A presença dos cubos de espuma de poliuretano servindo como suporte para as bactérias e a não fixação destes no tubo, pode levar o entupimento do encanamento que interliga os tubos dos biorreatores, ocasionada pela força exercida no líquido através da bomba havendo um acúmulo de material nas extremidades destas interligações. Justificando assim o monitoramento periódico da saída do efluente dos biorreatores.

Adicionando a estes cuidados foram coletadas amostras semanais para averiguação da concentração de formol presente tanto na entrada (antes dos biorreatores, na Caixa de Equalização) quanto na saída do último biorreator para a rede coletora de esgoto. Neste caso, houve a necessidade de treinamento da equipe do Laboratório Multidisciplinar para manusear amostras e fazer as análises no próprio laboratório, além de adquirir materiais de consumo e insumo necessário para a prática. Após os detalhes dos biorreatores atribuímos moderado como ocorrência de falhas (índice igual a 3), índice igual a 5 (cinco) na variável de severidade por não haver possibilidade de recuperação do efluente após a sua passagem. E a terceira variável é de probabilidade média de detectar a falha (índice igual a 3), resultando nesta etapa um índice de risco igual a $45(\mathrm{IR}=45)$.

\subsubsection{Fluxograma do Processo}

Com o conhecimento de todas as etapas e todos os pontos críticos foi possível a organização das figuras 17 e 18, mapeando todo o sistema desde o local gerador até a disposição do efluente para a rede coletora de esgoto municipal. A figura 18 foi elaborada para mapear os pontos críticos existentes, desenvolvendo juntamente com a equipe do laboratório um protocolo de operação minimizando ao máximo a possibilidade de falhas durante o procedimento. 


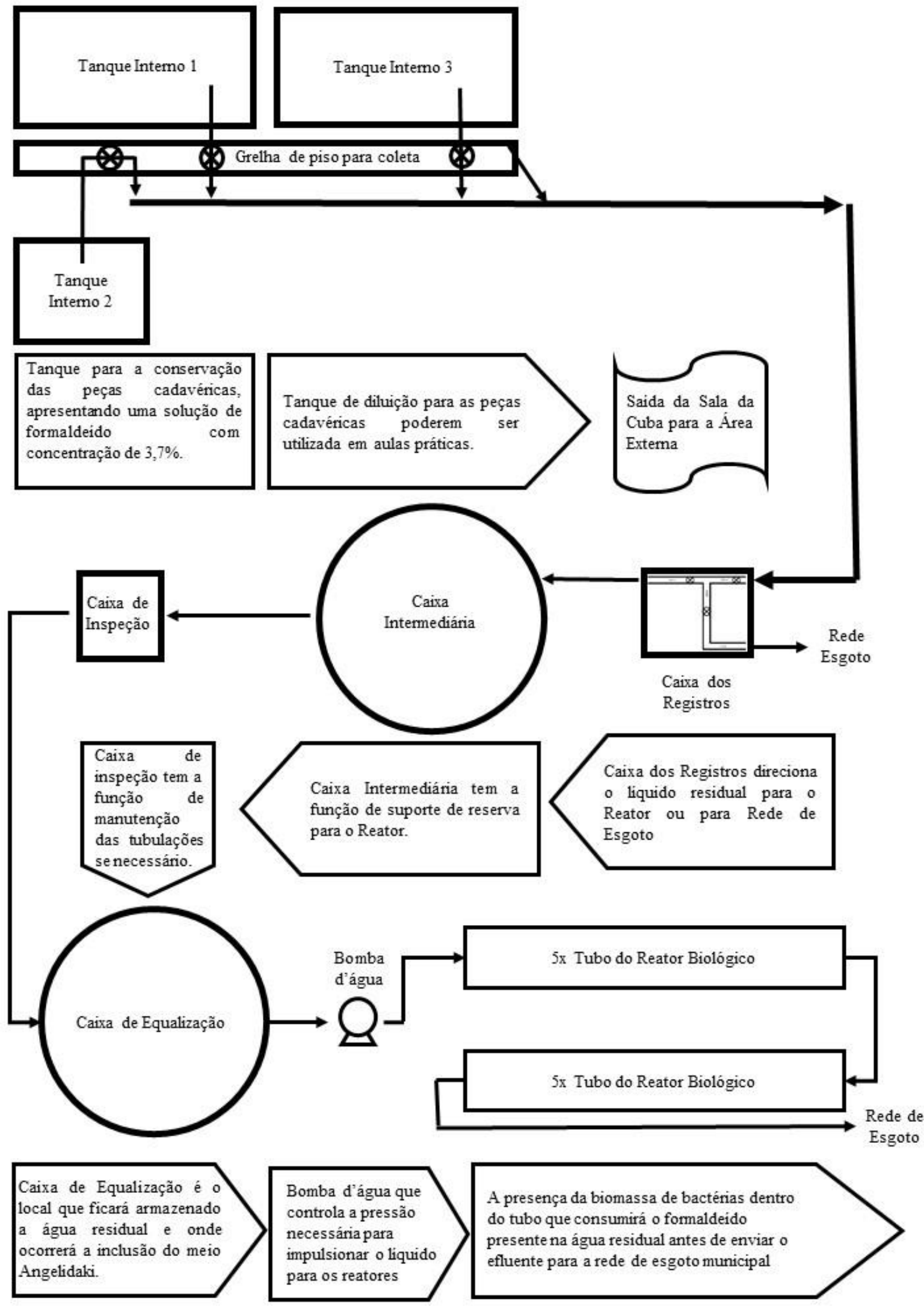

Figura 17- Fluxograma do mapeamento do processo do sistema de tratamento implantado na EERP/ USP. 


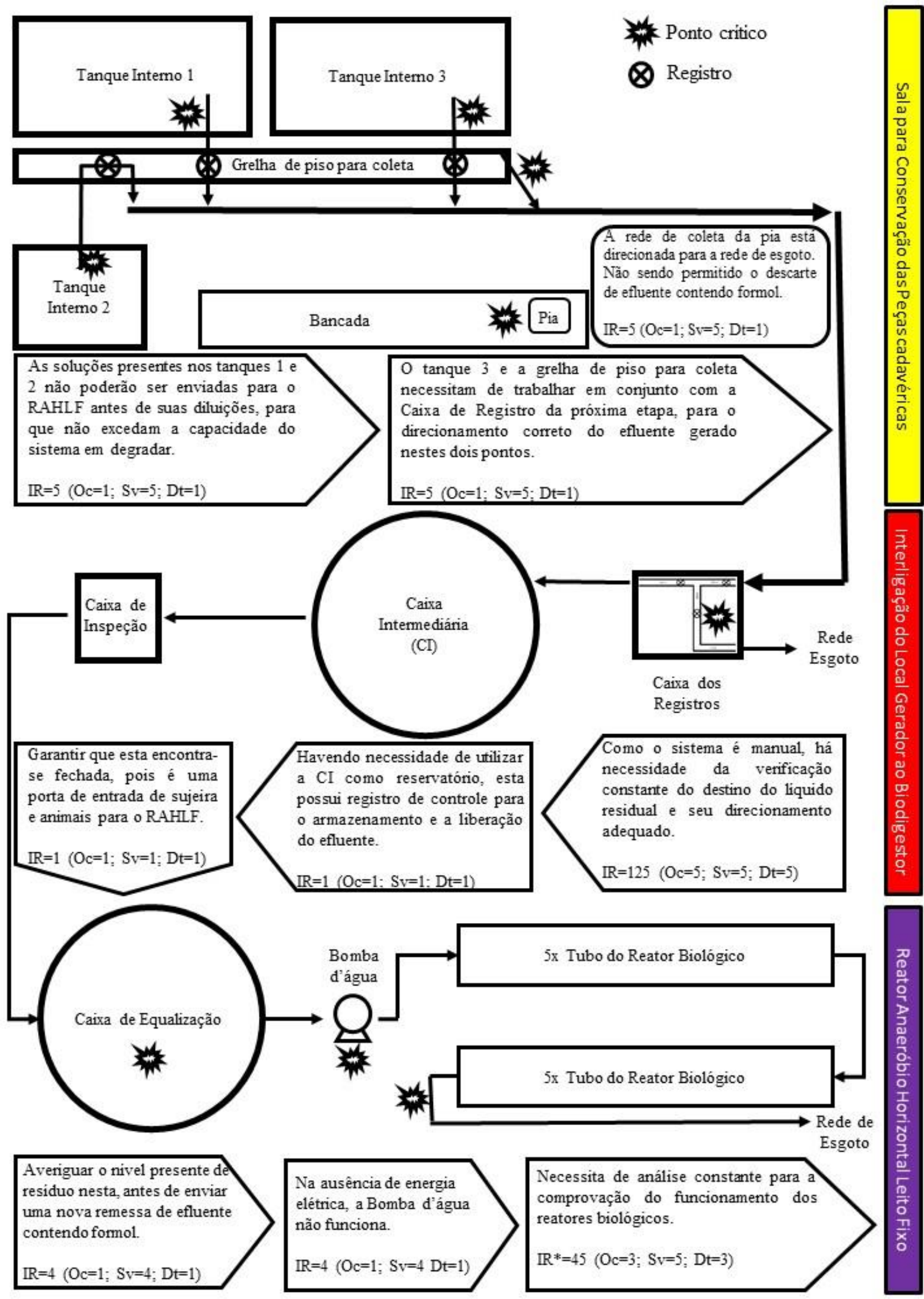

Figura 18- Fluxograma do mapeamento do processo do envio do efluente do local gerador até a rede coletora de esgoto descrito com os pontos críticos. 
Considerando o impacto ambiental do formaldeído, que ocupa o primeiro lugar dentre uma lista composta por 45 produtos químicos descrita por Priya et al. (2009), os efluentes contendo soluções de formol devem ser tratados criteriosamente por sistemas que possibilitem sua degradação. O descarte dos efluentes contendo concentrações inadequadas de formol coloca em risco não só os recursos naturais, mas compromete também a qualidade de vida das atuais e futuras gerações. Diante da metodologia de ensino adotada na disciplina de Anatomia nos cursos de Enfermagem da EERP/USP, que requer da conservação de peças cadavéricas no Laboratório Multidisciplinar, dessa forma, considera-se a implantação do sistema de tratamento das soluções de formol um avanço em termos ambientais, levando-se em conta os resultados obtidos neste estudo. A implantação de sistemas de tratamento de efluentes gerados em atividades de ensino/pesquisa no âmbito da universidade, reflete o rigor e a responsabilidade ambiental que as instituições de ensino superior devem primar em prol de um planeta mais sustentável. Tais ações estão consonância com as iniciativas da Organização Mundial da Saúde (OMS), tanto humana quanto animal, e da Organização das Nações Unidas para alimentação e agricultura (FAO), as quais integram a saúde humana, animal e a do meio ambiente. 


\section{CONCLUSÃO}

No ano de 2017 a EERP/USP implementou o RAHLF, em consonância com modelo publicado por Oliveira et al. (2004), dimensionado para atender grandes volumes de efluentes com solução de formol gerados na unidade. Portanto, este estudo inédito em escala industrial, permitiu a avaliação do reator anaeróbio implantado, que consiste em um sistema de tratamento de efluente contendo formol antes do envio dos mesmos para a rede coletora municipal. Além de monitorar a eficiência da remoção da solução de formol dos efluentes gerados no sistema de biorreatores também caracterizamos os pontos críticos de controle do processo de tratamento do RAHLF, durante o período de fevereiro a junho e de setembro a novembro do ano de 2020.

A partir dos resultados obtidos em estudo, concluímos que o RAHLF apresentou desempenho satisfatório para o pré-tratamento de água residuária contendo formol, visto que a eficiência na remoção do formol dos efluentes gerados foi em média de 99,70\%. O reator também apresentou estabilidade de operação durante o desenvolvimento do estudo.

Após o mapeamento de todas as etapas e dos pontos críticos do processo foi possível a organização de um fluxograma, permitindo o desenvolvimento de ações para minimizar ocorrências e potenciais falhas que possam comprometer a degradação do formol e dessa forma evitar impactos ambientais tóxicos.

Este estudo está em linha com o conceito de Saúde Única (One health - OH), cujos esforços integrados e multidisciplinares visam garantir o equilíbrio entre três pilares da saúde humana, saúde animal e a do meio ambiente. A implantação e funcionamento adequado do biodigestor refletem o compromisso socioambiental da universidade com a sociedade e com o meio ambiente, na busca de ações que promovam tanto a saúde pública quanto a sustentabilidade ambiental. Este estudo gerou conhecimento que contribui para uma melhor compreensão da biotecnologia anaeróbia implantada para a degradação das soluções de formol no efluente do Laboratório Multidisciplinar da EERP/USP. Os resultados constituirão também uma base de dados para outros gestores de biodigestores implantados na universidade, sendo de grande importância para a continuidade de investigações relacionadas com o tratamento dos efluentes em laboratórios de ensino. 


\section{REFERÊNCIAS}

ALMEIDA, D. A.; LEAL, F.; PINHO, A.F.; FAGUNDES, L.D. Gestão do Conhecimento na análise de falhas: mapeamento de falhas através de sistema de informação. Revista Produção, v. 15, n. 1, p. 171-188, 2006.

ALVARENGA, J. Possibilidades e limitações da utilização de membranas biológicas preservadas em cirurgia, Tópicos em Cirurgia de Cães e Gatos, In: Daleck C.R., Jaboticabal Fundação de Estudos e Pesquisas em Agronomia, p.33-39, 1992.

ALVES, C.A.; ACIOLE, S.D.G. Formaldeído em escolas: uma revisão. Quím. Nova, São Paulo, v.35, n.10, p.2025-2039, 2012.

ANGELIDAKI, I; PETERSEN, S.P.; AHRING, B.K. Effects of lipids on thermophilic anaerobic digestion and reduction of lipid inhibition upon addition of bentonite. Applied Microbiology Biotechnology, v.33, p.469-472, 1990.

ANYANWU, G.E.; UDEMEZUE, O.O.; OBIKILI, E.N. Dark age of sourcing cadavers in developing countries: a nigerian survey. Clin. Anat, v 24, p. 831-836, 2011.

ARAUJO, L. O. C.; AQUINO, J. P. R.; ROTONDARO, R. G. Análise e Aplicabilidade das Ferramentas da Qualidade no Serviço de Fôrmas como Auxílio ao Planejamento para Produção. Salvador - BA. In: ENEGEP, 21, 2001.

ASSUMPÇÃO, R.M.V.; MORITA, T. Manual de soluções, reagentes e solventes. Ed. Edgard Blücher Ltda, São Paulo, 1968.

ATSDR - Agency for Toxic Substances and Disease Registry; Toxicological profile for formaldehyde. ATSDR: Atlanta, 1999.

BABINSKI, M.A.; SGROTT, E.A.; LUZ, H.P.; BRASIL, F.B.; CHAGAS, M.A.; ABIDUFIGUEIREDO, M. La relación de los estudiantes con el cadáver en el estudio práctico de anatomía: La relación e influencia en el aprendizaje. Int. J. Morphol, v. 21, n. 2, p. 137 - 42, 2003.

BAILEY, B.W.; RANKIN, J.M. New spectrophotometric method for determination of formaldehyde. Analytical Chemistry, v.43, n.6, p.782-84, 1971.

BARNES, R. M. Estudo de movimentos e de tempos. Tradução da $6^{\text {a }}$ edição americana. $9^{\mathrm{a}}$ reimpressão. São Paulo: Edgard Blücher, 2004.

BASTOS, A. L. A. FMEA como Ferramenta de Prevenção da Qualidade em Produtos e Processos - Uma Avaliação da Aplicação em um Processo Produtivo de Usinagem de Engrenagem. Fortaleza - CE. In: ENEGEP, 26, 2006.

BLACHE, K.M.; SHRIVASTAVA, A.B. Defining Failure of manufacturing and equipment. In: Proceedings of Annual Reliability and Maintainnability Symposium (RAMS). p. 69-75, 1994. 
BRASIL. Lei n 8.501, de 30 de novembro de 1992, que dispõe sobre a utilização de cadáver não reclamado, para fins de estudos ou pesquisas científicas e dá outras providências. Diário Oficial da União - Seção 1 - 1/12/1992, Página 16519 (Publicação Original).

BRASIL. Lei n ${ }^{\circ}$ 9.434, de 04 de fevereiro de 1997, que dispõe sobre a remoção de órgãos, tecidos e partes do corpo humano para fins de transplante e tratamento e dá outras providências. Diário Oficial da União - Seção 1 - 5/2/1997, Página 2191 (Publicação Original).

BRASIL. Lei no 10.406 , de 10 de janeiro de 2002, que institui o Código Civil. Diário Oficial da União de 11/01/2002, Página $n^{\circ} 1$.

BRASIL. Lei $n^{\circ}$ 12.305, de 02 de agosto de 2010, que institui a Política Nacional de Resíduos Sólidos; altera a Lei ${ }^{\circ} 9.605$, de 12 de fevereiro de 1998; e dá outras providências. Data da Legislação: 02/08/2010 - Diário Oficial da União, de 03/08/2010.

CARMO, A.T.; PRADO, R.T.A. Qualidade do Ar Interno. Texto Técnico da Escola Politécnica da USP. TT/PCC/23, São Paulo, 1999.

CHEUNG, Y.; BAL, J. Process analysis techniques and tools for business improvements. Business Process Management Journal, v. 4, n. 4, p. 274-290, 1998.

COLLIPAL, L.E.; SILVA, M.H. Estudio de la anatomía en cadáver y modelos anatómicos: impresión de los estudiantes. Int. J. Morphol., Temuco, v. 29, n. 4, p. 1181-1185, 2011.

COSTA, G.B.F. O cadáver no ensino da anatomia humana: uma visão metodológica e bioética. Revista Brasileira de Educação Médica, Pernambuco, v. 36, n. 3, p. 369-373, 2012.

DA NOVA, J.L.L.; BEZERRA FILHO, J.J.; BASTOS, L.A.M. An anatomy lesson. Interface: comunicação, saúde, educação, v. 4, n 6, p. 87 - 96, 2000.

DI DIO, L.J.A. Tratado de anatomia aplicada. São Paulo: Poluss, 1998.

EERP/USP (ESCOLA DE ENFERMAGEM DE RIBEIRÃO PRETO/USP) Marco Histórico da Escola de Enfermagem de Ribeirão Preto. Disponível em:

http://www.eerp.usp.br/corporate-historia-marcos-historicos/ Acesso em: 14 mar. 2020.

ELIAS, J.A.; LEE, C.G.; ZHENG, T.; MA, B.; HOMER, R.J.; ZHU, Z. New insights into the pathogenesis of asthma. Journal Clin. Invest., v.111, n. 3, p. 291-297, 2003.

FAGUNDES, L. D.; ALMEIDA, D. A. Mapeamento de falhas em concessionárias do setor elétrico: padronização, diagramação e parametrização. Bauru - SP. In: XI SIMPEP, 2004.

FAZAN, V.P.S. Métodos de ensino em anatomia: dissecação versus prossecção. O Anatomista, v 1, n.2, p. 7-11, 2011.

FERREIRA, M.T.; COELHO, C.; GAMA, I. Application of forensic anthropology to nonforensic issues: an experimental taphonomic approach to the study of human body 
decomposition in aerobic conditions. Australian Journal of Forensic Sciences, DOI: 10.1080/00450618.2017.1329850. 2017.

FISPQ (FICHA DE INFORMAÇÕES DE SEGURANÇA DE PRODUTOS QUÍMICOS) Formaldeído, no 104002. MERCK, Revisada em 17/07/2017.

FORNAZIERO, C.C.; GORDAN, P.A.; CARVALHO, M.A.V.; ARAUJO, J.C.; AQUINO, J.C.B. O ensino da anatomia: integração do corpo humano e meio ambiente. Revista Brasileira de Educação Médica, Rio de Janeiro, v. 34, n. 2, p. 290-297, 2010.

GIGEK, T.; OLIVEIRA, J.E.M.; NETO, A.C.A.; CARVALHO, W.L.; PEREIRA, F.V.; ALMEIDA, A.H. Estudo Analítico da Técnica de Glicerinação Empregada para Conservação de Peças Anatômicas de Bovinos. In: SIMPÓSIO DE CIÊNCIAS DA UNESP, 5, 2009, Dracena. Anais do V Simpósio de Ciências da UNESP. Dracena: UNESP, 2009, p. 1-3.

GONZÁLEZ, J.A.M.; CASTRO I.C. Técnicas de conservación en anatomía. Lima, 1989.

GONZALEZ-GIL G.; KLEEREBEZEM R.; LETTINGA G. Conversion e Toxicity Characteristics of formaldehyde in acetoclastic methanogenic sludge. Biotecnology e bioengineering, v. 79, n. 3, p. 314- 322. 2002.

HELMAN, H.; ANDERY, P. R. P. Análise de Falhas: aplicação dos métodos de FMEA e FTA. Belo Horizonte: Fundação Cristiano Ottoni, Escola de Engenharia da UFMG, 1 ed., 1995.

HUNT, V. D. Process Mapping: How to Reengineer your Business Process. New York: John Wiley \& Sons, 1996.

IARC (INTERNATIONAL AGENCY FOR RESEARCH ON CANCER) Formaldehyde, 2Butoxyethanol and 1-tert-Butoxypropan-2-ol. IARC, Lyon, 2006.

IBGE (INSTITUTO BRASILEIRO DE GEOGRAFIA E ESTATÍSTICA). Panorama da cidade de Ribeirão Preto. Disponível em: https://cidades.ibge.gov.br/brasil/sp/ribeiraopreto/panorama, Acesso em: 22 de abril de 2021.

JUNQUEIRA, L.C.; CARNEIRO, J. Histologia Básica. $8^{\circ}$ edição. Rio de Janeiro. Editora Guanabara Koogan, 2005.

KADEN, D.A.; MANDIN, C.; NIELSEN, G.D.; WOLKOFF, P. WHO Guidelines for Indoor Air quality: selected pollutants. Regional Office for Europe of the World Health Organization, Copenhagen, c. 3, 2010.

KERBY, J.; SHUKUR, Z.N.; SHALOUB, J. The relationships between learning outcomes and methods of teaching anatomy as perceived by medical students. Clin. Anat, v. 24, p. 489 $-497,2011$.

KRUG, L.; PAPPEN, F.G.; ZIMERMANN, F.C.; DEZEN, D.; RAUBER, L.P.; SEMMELMANN, C.; ROMAN, L.I.; BARRETA, M.H. Conservação de peças anatômicas com glicerina loira. In: Mostra de Iniciação Científica, 1, 2011, Concórdia. Anais. Concórdia - Santa Catarina, 2011. 
MATOS, R. B.; MILAN, M. Aplicação sistêmica do modo de análise de falhas e efeitos (FMEA) para o desenvolvimento de indicadores de desempenho de empresas de pequeno porte. Rev. Árvore, Viçosa, v. 33, n. 5, p. 977-985, 2009.

MCGWIN, G.; LIENERT, J.; KENNEDY, J.I. Formaldehyde exposure and asthma in children: a systematic review. Environ. Health Persp, v.118, n. 3, p. 313-317, 2010.

MELLO, C. H. P.; SALGADO, E. G. Mapeamento dos processos em serviços: estudo de caso em duas pequenas empresas da área de saúde. In: Encontro Nac. de Eng. de Produção, 25, 2005, Porto Alegre. Anais. Porto Alegre: 2005, p. 1715-1722.

MOMPEO, B; PEREZ, P. Relevance of gross human anatomy in health primary care and in clinical disciplines of medical studies. Educación Médica, v.6, n.1. p. 47-57, 2003.

MOSLEY, M.; LYNCH, J. Uma história da ciência: experiência, poder e paixão. Rio de Janeiro: Zahar, 2011.

NEVES, M.V.S. Uma nova proposta no ensino da anatomia humana: desafios e novas perspectivas. 2010. 56p. Dissertação (Mestrado) - Centro Universitário de Volta Redonda UniFOA, Volta Redonda, 2010.

OLIVEIRA, I.M.; MINDÊLLO, M.M.A.; MARTINS, Y.O.; SILVA FILHO, A.R. Análise de peças anatômicas preservadas com resina de poliéster para estudo em anatomia humana. Rev. Col. Bras. Cir, v. 40, n. 1, p. 76-80, 2013.

OLIVEIRA, S.V.W.B. Avaliação da degradação e toxicidade de formaldeído em reator anaeróbio horizontal de leito fixo. 2001. 95p. Dissertação (Mestrado) - Escola de Engenharia de São Carlos, Universidade de São Paulo, São Carlos, 2001.

OLIVEIRA, S.V.W.B; MORAES, E.M.; ADORNO, M.A.T.; VARESCHE, M.B.A.; FORESTI, E.; ZAIAT, M. Formaldehyde degradation in an anaerobic packed-bed bioreactor. Water Research, v. 38, n. 7, p.1685-1694, 2004.

OLIVEIRA, U.R.; PAIVA, E.J.; ALMEIDA, D.A. Metodologia integrada para mapeamento de falhas: uma proposta de utilização conjunta do mapeamento de processos com as técnicas FTA, FMEA e a análise crítica de especialistas. Produção, v. 20, n. 1, jan/mar, p. 77-91, 2010.

PALADY, P. FMEA Análise dos Modos de Falha e Efeitos. São Paulo: IMAN, 1997.

PHILIPPI Jr, A. Saneamento, saúde e ambiente: fundamentos para um desenvolvimento sustentável. São Paulo, 2005.

PIAZZA, B. L.; CHASSOT, A. I. Anatomia humana, uma disciplina que causa evasão e exclusão: quando a hipótese principal não se confirma. Ciência em Movimento, Porto Alegre, v. 14, n. 28, p. 45-59, 2011.

PRIYA, K.R.; SANDHYA, S.; SWAMINATHAN, K. Kinetic analysis of treatment of formaldehyde containing wastewater in UAFB reactor. Chemical Engineering Journal, v. 148, n. 2, p. 212-216, 2009. 
PRZYBYSZ, C. H.; SCOLIN, E. Avaliação do formaldeído como fungicida no laboratório de anatomia humana. Rev F@ pci, v. 5, n. 12, p. 121-133, 2009.

QU, M; BHATTACHARYA, S.K. Toxicity e biodegradation of formaldehyde in anaerobic methanogenic culture. Biotechnology e bioengineering, v. 55, n. 5, p. 727-736, 1997.

RAUSAND, M.; OIEN, K. The basic concepts of failure analysis. Reliability Engineering and System Safety, v. 53, n. 1, p. 73-83, 1996.

RIZZOLO, L.J.; STEWART, W.B. Should we continue teaching anatomy by dissection when...? Anat Rec B New Anat, v. 289, n. 6, p. 215-218, 2006.

RODRIGUES, H. Técnicas Anatômicas. 3.ed. Vitória: Arte Visual, 2005.

SANTOS, A.A.; SILVA, M.G.V.; SANTOS, J.L.; MELO, P.G.B. Principais métodos de fixação de peças para estudo anatômico: uma revisão de literatura. Arquivos do MUDI, v 21, n 01, p. 19-25, 2017.

SÃO PAULO. Decreto $n^{\circ}$ 8.468, de 8 de setembro de 1976, regulamento da lei $n^{\circ}$ 997, de 31 de maio de 1976, que dispõe sobre a prevenção e o controle da poluição do meio ambiente.

Diário Oficial - Poder Executivo, 09/09/1976, p.4.

SCHMITT, J. C. Método de análise de falha utilizando a integração das ferramentas DMAIC, RCA, FTA e FMEA. 2013. 98 f. Dissertação (Mestrado em Engenharia de Produção) -Faculdade de Engenharia, Arquitetura e Urbanismo, da Universidade Metodista de Piracicaba, Piracicaba, 2013.

SHARMA, R. K.; KUMAR, D.; KUMAR, P. Systematic failure mode effect analysis (FMEA) using fuzzy linguistic modeling. International Journal of Quality \& Reliability Management, v. 22, n. 9, p. 986-1004, 2005.

SILVA E.M.; DIAS, G.; TAVARES, M.; MARQUES, T.; FURTADO, J.M. Estudo analítico da técnica de glicerinação empregada para conservação de peças anatômicas: experiência da disciplina de Anatomia Humana do Departamento de Morfologia da UniFOA. Cadernos UniFOA, Ed. Especial, ano 3, p.66-69, 2008.

SILVA, G.R.; CORTEZ, P.O.B.C.; LOPES, I.S.L.; TEIXEIRA, B.A.C.B.; LEAL, N.M.S. Métodos de conservação de cadáveres humanos utilizados nas faculdades de medicina.

Revista Medicina, v. 95, n. 4, p. 156-61, 2016.

SINGER, C. Uma breve história da anatomia e fisiologia desde os gregos até Harvey. Campinas: Editora da Unicamp, 1996, p.48.

SLACK, N.; CHAMBERS, S.; JOHNSTON, R. Administração da Produção. São Paulo: Atlas, 2002.

STAMATIS, D.H. Failure mode and effect analysis: FMEA from theory to Execution. ASQ Quality Press, 495 p., Wisconsin, USA, 1995. 
TAVANO, P.T.; OLIVEIRA, M.C. Surgimento e desenvolvimento da ciência anatômica. Anuário da Produção Acadêmica Docente, v. II, n. 3, 2008.

THOMPSON, C.M.; SUBRAMANIAM, R.P.; GRAFSTROM, R.C. Mechanistic and dose considerations for supporting adverse pulmonary physiology in response to formaldehyde. Toxicol. Appl. Pharm, v. 233, n. 3, p. 255-359, 2008.

VAN DE GRAAF, K. M. Anatomia humana. $6^{\circ}$ ed. São Paulo. Editora Manole, 2003.

VIDAL, G.; JIANG, Z.P.; OMIL, F.; THALASSO, F.; MÉNDEZ, R.; LEMA, J.M. Continuous anaerobic treatment of wastewaters containing formaldehyde and urea. Bioresource Technology, v.70, p.283-91, 1999.

YANG, C.; LIN, W.; LIN, M.; HUANG, J. A study on applying FMEA to improving ERP introduction an example of semiconductor related industries in Taiwan. International Journal of Quality \& Reliability Management, v. 23, n. 3, p. 298-322, 2006.

ZOUTBERG, G.R.; DE BEEN, P. The Biobed® EGSB (expanded granular sludge bed) system covers shortcomings of the up flow anaerobic sludge blanket reactor in the chemical industry. Water Science and Technology, v. 35, n. 10, p. 183-8, 1997. 